Article

\title{
Cold-Adapted Live Attenuated SARS-Cov-2 Vaccine Completely Protects Human ACE2 Transgenic Mice from SARS-Cov-2 Infection
}

\author{
Sang Heui Seo $1,2, *$ (i) and Yunyueng Jang ${ }^{1,2}$ \\ 1 Laboratory of Influenza Research, College of Veterinary Medicine, Daejeon 34134, Korea; jyy1915@naver.com \\ 2 Institute of Influenza Virus, Chungnam National University, Daejeon 34134, Korea \\ * Correspondence: seos@cnu.ac.kr; Tel.: +82-42-821-7819; Fax: +82-42-821-6762
}

Received: 28 August 2020; Accepted: 1 October 2020; Published: 3 October 2020

check for updates

\begin{abstract}
A safe and effective vaccine that can provide herd immunity against severe acute respiratory syndrome coronavirus (SARS-CoV-2) is urgently needed to stop the spread of this virus among humans. Many human viral vaccines are live, attenuated forms of viruses that elicit humoral and cellular immunity. Here, we describe a cold-adapted live-attenuated vaccine (SARS-CoV-2/human/Korea/CNUHV03-CA22 ${ }^{\circ} \mathrm{C} / 2020$ ) developed by gradually adapting the growth of SARS-CoV-2 from $37{ }^{\circ} \mathrm{C}$ to $22{ }^{\circ} \mathrm{C}$ in Vero cells. This vaccine can be potentially administered to humans as a nasal spray. Its single dose strongly induced neutralising antibodies (titre $>640$ ), cellular immunity, and mucosal IgA antibodies in intranasally immunised K18-hACE2 mice, which are very susceptible to SARS-CoV-2 and SARS-CoV infections. The one-dose vaccinated mice were completely protected from SARS-CoV-2 infection and did not show body weight loss, death, or the presence of virus in tissues, such as the nasal turbinates, brain, lungs, and kidneys. These results demonstrate that the cold-adapted live attenuated SARS-CoV-2 vaccine we have developed may be a candidate SARS-CoV-2 vaccine for humans.
\end{abstract}

Keywords: SARS-CoV-2; live attenuated vaccine; cold adaptation

\section{Introduction}

In December 2019, human cases of mysterious severe pneumonia were reported from the city of Wuhan in eastern China [1,2]. The initial symptoms were found to be similar to those of patients infected with Severe Acute Respiratory Syndrome (SARS) virus. Sequencing of the causative agent showed that its genome was similar to that of SARS, leading to its designation as Severe Acute Respiratory Syndrome Coronavirus-2 (SARS-CoV-2) [1,2]. The World Health Organization (WHO) declared coronavirus disease 2019 (COVID-19), the disease caused by SARS-CoV-2, as a pandemic on 11 March 2020.

SARS-CoV-2 belongs to the family of coronaviruses, which are enveloped, positive-sense single-stranded RNA viruses [3]. The genome size of SARS-CoV-2 is about $30 \mathrm{~kb}$. SARS-CoV-2 consists of four structural proteins, namely nucleocapsid $(\mathrm{N})$, membrane $(\mathrm{M})$, envelope $(\mathrm{E})$, and spike $(\mathrm{S})$ proteins, which form the structural backbone of the virus; sixteen non-structural proteins (nsp1-nsp16); and several accessory proteins [4]. The S protein is located on the surface of SARS-CoV-2 and binds to the human angiotensin converting enzyme 2 (hACE2) receptor to initiate the infection $[5,6]$.

Patients infected with SARS-CoV-2 commonly show fever, cough, myalgia, and fatigue, and some patients might also develop acute respiratory distress syndrome (ARDS) [7]. Among the 99 patients infected with SARS-CoV-2 in Wuhan, China, 74 showed bilateral pneumonia, 14 showed multiple mottling and ground-grass opacity in the lungs, and one patient had pneumothorax; 17 patients had 
ARSD, and 11 of these patients died of multiple organ failure [8]. In Washington, USA, ARDS was observed in 15 of 21 patients, and mechanical ventilation was required for these patients [9]. In addition to pneumonia and ARDS, SARS-CoV-2 is responsible for clinical signs related to the affliction of the central nervous system (CNS); these include loss of taste and smell, headaches, twitching, seizures, vision impairment, nerve pain, dizziness, impaired consciousness, nausea, vomiting, hemiplegia, ataxia, stroke, and cerebral haemorrhage $[10,11]$.

To date, there is no effective licensed vaccine for SARS-CoV-2. Therefore, there is an urgent need to develop a safe and effective SARS-CoV-2 vaccine to protect humans from the COVID-19 pandemic. Various types of SARS-CoV-2 vaccines are under development; these include DNA- and mRNA-based vaccines, encoding the S protein of SARS-CoV-2 [12-14], adenovirus-, measles virus-, and vesicular stomatitis virus-based vectors expressing the $S$ gene [15-18], and a purified inactivated vaccine [19]. Most of the licensed human viral vaccines, such as those against measles, mumps, rubella, rotavirus, smallpox, chickenpox, yellow fever, and influenza virus (nasal inoculation), are live attenuated forms of the respective virus [20-27]. Cold-adapted live influenza vaccines for seasonal influenza viruses are produced in primary chick kidney cells or embryonated eggs at $25^{\circ} \mathrm{C}$ and are administered intranasally to humans $[26,27]$. Live attenuated vaccines are similar to natural infectious agents; they a elicit strong and long-lasting immune response, and thereby, have good protective effects in humans.

In this study, we developed a cold-adapted live attenuated SARS-CoV-2 vaccine strain by gradually adapting the growth of SARS-CoV-2 virus from $37^{\circ} \mathrm{C}$ to $22^{\circ} \mathrm{C}$ in Vero cells. The attenuation of the SARS-CoV-2 vaccine strain (designated as SARS-CoV-2/human/Korea/CNUHV03-CA22 ${ }^{\circ} \mathrm{C} / 2020$ ) and its efficacy as a vaccine was confirmed in hACE-2 transgenic mice (K18-hACE2 mice), to which infections by SARS-CoV and SARS-CoV-2 are lethal [28-32].

\section{Materials and Methods}

\subsection{Animals}

Female (5-6-week-old) human angiotensin converting enzyme 2 (ACE-2) transgenic mice (B6.Cg- Tg(K18-ACE2)2Prlmn/J) (referred to as K18-hACE2 in this paper) were kindly provided by The Jackson Laboratory (Bar Harbor, Maine, USA). The mice were fed a standard chow diet and water.

\subsection{Viruses and Cells}

The SARS-CoV-2 strain (SARS-CoV-2/human/Korea/CNUHV03/2020) (referred to as CoV-2CNUHV03 in this paper) (GenBank accession number: MT678839), isolated in our laboratory from a human clinical sample collected at the Chungnam National University Hospital (Daejeon, South Korea), and BetaCoV/South Korea/KCDC03/2020 (referred to as CoV-2-KCDC03 in this paper), which was provided by the Korean Centers for Disease Control and Prevention (KCDC), were propagated in Vero-E6 cells obtained from American Type Culture Collection (Manassas, VA, USA). Minimal essential medium (MEM), supplemented with $10 \%$ foetal bovine serum (FBS) and $1 \times$ antibiotic-antimycotic solution (Sigma, St. Louis, MO, USA), was used for the culture of cells. All experimental procedures involving potential contact with SARS-CoV-2 were conducted in a biosafety level 3 laboratory certified by the Korean government.

\subsection{Development of the Cold-Adapted Live Attenuated SARS-CoV-2 Vaccine Strain}

The SARS-CoV-2 strain (SARS-CoV-2/human/Korea/CNUHV03/2020) was gradually adapted from $37^{\circ} \mathrm{C}$ to $22^{\circ} \mathrm{C}$ in Vero cells in MEM with $200 \mathrm{mM}$ L-glutamine (Hyclone, South Logan, UT, USA), supplemented with 1.5\% bovine serum albumin (BSA; Rocky Mountain Biologicals, Missoula, MT, USA) and $1 \times$ antibiotic-antimycotic solution (Sigma). Vero cells were cultured in MEM with 10\% FBS in a humidified $5 \% \mathrm{CO}_{2}$ incubator $\left(37^{\circ} \mathrm{C}\right)$ and washed twice with warm PBS (pH 7.4). The washed Vero cells were inoculated with SARS-CoV-2 virus (SARS-CoV-2/human/Korea/CNUHV03/2020) and 
incubated in a humidified $5 \% \mathrm{CO}_{2}$ incubator (from $37{ }^{\circ} \mathrm{C}$ to $22{ }^{\circ} \mathrm{C}$ ). When the infected Vero cells showed cytopathic effects (CPE), the next lower temperature was used to adapt the virus. It took about $3-4$ days from $37{ }^{\circ} \mathrm{C}$ to $28^{\circ} \mathrm{C}$, about $4-5$ days from $25^{\circ} \mathrm{C}$ to $27^{\circ} \mathrm{C}$, about $7-10$ days from $22{ }^{\circ} \mathrm{C}$ to $24{ }^{\circ} \mathrm{C}$ to observe the $\mathrm{CPE}$ in the infected cells. We confirmed the viral presence in the supernatants by quantitative real-time PCR using SARS-CoV-2 $\mathrm{N}$ primers and TCID50 in Vero cells. When SARS-CoV-2 virus was successfully passaged at $22{ }^{\circ} \mathrm{C}$ more than five times (>passage $=5$ ), it was used for the vaccine study, and for sequencing of the whole genome. The cold-adapted live attenuated vaccine strain was designated as SARS-CoV-2/human/Korea/CNUHV03-CA22 ${ }^{\circ} \mathrm{C} / 2020$ (referred to as $\mathrm{CoV}-2-\mathrm{CNUHV} 03-\mathrm{CA} 22{ }^{\circ} \mathrm{C}$ in this paper). At passage 5 , at $22{ }^{\circ} \mathrm{C}$, the SARS-CoV-2 cold-adapted vaccine virus was cloned by limited-dilution infection in Vero cells in 96-well plates three times. Virus titres for the cold passaged SARS-CoV-2 were determined by RT-qPCR using SARS-CoV-2 $\mathrm{N}$ primers and Taqman probe and by plaque assay at $22{ }^{\circ} \mathrm{C}$ in terms of pfu.

\subsection{Confirmation of Temperature Sensitivity of the Cold-Adapted Live Attenuated SARS-CoV-2 Vaccine Strain}

Vero cells grown to confluence in 6-well plates were infected with 0.00001 or 0.000001 multiplicity of infections (m.o.i) of CoV-2-CNUHV03-CA22 ${ }^{\circ} \mathrm{C}$ and wild-type SARS-CoV-2 (CoV-2-CNUHV03). The infected cells were incubated in a humidified $5 \% \mathrm{CO}_{2}$ incubator at $37^{\circ} \mathrm{C}$ or $41{ }^{\circ} \mathrm{C}$, and virus titres in the supernatants were quantified 3 days later by RT-qPCR using the SARS-CoV- $2 \mathrm{~N}$ primers and probe.

\subsection{Measurement of Plaque Forming Units by Plaque Assay}

Stocks of SARS-CoV-2 (CoV-2-CNUHV03 or CoV-2-CNUHV03-CA22 ${ }^{\circ} \mathrm{C}$ ) were serially 10 -fold diluted in MEM with 1.5\% BSA. Confluent Vero cells growing in 24-well plates were infected with the diluted virus suspensions for $4 \mathrm{~h}$ in a humidified $5 \% \mathrm{CO}_{2}$ incubator $\left(37^{\circ} \mathrm{C}\right.$ for $\mathrm{CoV}-2-\mathrm{CNUHV} 03$ and $22{ }^{\circ} \mathrm{C}$ for $\mathrm{CoV}-2-\mathrm{CNUHV} 03-\mathrm{CA} 22^{\circ} \mathrm{C}$ ). After removing the inoculum, Vero cells were overlaid with $1 \%$ electrophoretic agar (LPS Solution, Korea) in MEM and incubated for 4 or 7 days in a humidified $5 \% \mathrm{CO}_{2}$ incubator $\left(37^{\circ} \mathrm{C}\right.$ for $\mathrm{CoV}-2-\mathrm{CNUHV} 03$ and $22{ }^{\circ} \mathrm{C}$ for CoV-2-CNUHV03-CA22 $\left.{ }^{\circ} \mathrm{C}\right)$. The cells were then stained with $0.1 \%$ crystal violet (Sigma-Aldrich, St. Louis, MO, USA) prepared in 37\% formaldehyde solution, or with SARS-CoV-2 NP antibody and fluorescent-labelled secondary antibody. After removal of agar, the cells were fixed and permeabilised with $80 \%$ cold acetone (Samchun Pure Chemical Co., Gyeonggi-do, Korea). The cells were treated with SARS-CoV-2 nucleocapsid rabbit polyclonal antibody (Thermo Fisher Scientific, Waltham, MA, USA) and subsequently with fluorescent-labelled goat anti-rabbit antibody (Thermo Fisher Scientific). The number of plaques was counted under a fluorescence microscope (Olympus, Tokyo, Japan).

\subsection{Measurement of Virus Titres Using Real-Time Quantitative PCR}

RNA from virus samples was isolated using the RNeasy Mini Kit (QIAGEN, Hilden, Germany). Briefly, $100 \mu \mathrm{L}$ of supernatant containing the virus was disrupted in $350 \mu \mathrm{L}$ Buffer RLT, and then $550 \mu \mathrm{L}$ of $70 \%$ ethanol was added. The sample $(700 \mu \mathrm{L})$ was transferred to the RNeasy Mini spin column and subjected to centrifugation for $15 \mathrm{~s}$ at 13,500 rpm. After discarding the flow-through, $700 \mu \mathrm{L}$ of RW1 buffer was added to the spin column and it was centrifuged for $15 \mathrm{~s}$ at 13,500 rpm. The flow-through was discarded and $500 \mu \mathrm{L}$ of RPE buffer was added to the spin column before it was centrifuged for $15 \mathrm{~s}$ at $13,500 \mathrm{rpm}$. The spin column was then placed in a new $1.5 \mathrm{~mL}$ collection tube and viral RNA was eluted using $40 \mu \mathrm{L}$ of RNAse-free water.

To detect the virus, we used TaqMan real-time fluorescent PCR with TOPrealTM One-step RT qPCR Kit (Enzynomics, Daejeon, Korea) and SARS-CoV-2 N primers and probe. In a total volume of $20 \mu \mathrm{L}$, the following components were mixed: $5 \mu \mathrm{L}$ of TOPrealTM One-step RT qPCR Kit (TaqMan probe), $1 \mu \mathrm{L}$ of 10 pmol primers containing N_Sarbeco_F (5' -CACATTGGCACCCGCAAT-3'), N_Sarbeco-R (5'-GAGGAACGAGAAGAGGCTTG-3'), and N_Sarbeco_P (5'FAM-ACTTCCTCAA GGAACAACATTGCCA-3'BHQ1) [33], $10 \mu \mathrm{L}$ of viral RNA, and $2 \mu \mathrm{L}$ of nuclease-free water. Real-time amplification was performed on a Rotor-Gene 6000 system (QIAGEN, Hilden, Germany) using the 
following temperature profile: initial incubation at $50{ }^{\circ} \mathrm{C}$ for $30 \mathrm{~min}$ and at $95^{\circ} \mathrm{C}$ for $10 \mathrm{~min}$, followed by 45 cycles of $95^{\circ} \mathrm{C}$ for $5 \mathrm{~s}$ and $60^{\circ} \mathrm{C}$ for $30 \mathrm{~s}$. Standard curves were generated using data for stock viruses with known pfu titres determined by plaque assay.

\subsection{Confirmation of Attenuation of the Cold-Adapted Live Attenuated SARS-CoV-2 Vaccine Strain in hACE-2 Transgenic Mice}

K18-hACE2 mice were i.n. immunised with $50 \mu \mathrm{L}\left(2 \times 10^{4} \mathrm{pfu}\right)$ of the cold-adapted vaccine strain $(n=14)$ or wild-type virus $(n=10)$ after they were lightly anaesthetized with isoflurane USP (Gujarat, India). PBS (mock)-infected mice $(n=4)$ were used as controls. The infected mice were monitored for body weight change, and mortality. Six days p.i., three mice per virus (vaccine strain or wild-type virus)-infected group and one PBS (mock)-infected mouse were euthanized for determining virus titres in different tissues (nasal turbinates, brain, lungs, and kidneys) and for histopathology. Tissues (0.1 g per sample) were homogenised using a BeadBlaster homogeniser (Benchmark Scientific, Edison, NJ, USA) in $1 \mathrm{~mL}$ of PBS ( $\mathrm{pH}$ 7.4) to measure virus titres by RT-qPCR and by determining the $\log 10 \mathrm{TCID} 50 / 0.1 \mathrm{~g}$ values. The remaining portions of tissues were used for histopathology and antibody staining.

\subsection{Staining of Tissues by Haematoxylin and Eosin}

Mouse tissues were fixed in 10\% neutral buffered formalin (10\%) and then embedded in paraffin. The lung tissue was cut into $5 \mu \mathrm{m}$ sections, which were stained with haematoxylin $(\mathrm{H})$ solution for $4 \mathrm{~min}$. The stained tissue sections were washed with tap water for $10 \mathrm{~min}$ and then stained with eosin (E) solution. The stained sections were visualised under an Olympus DP70 microscope and photographed (Olympus Corporation, Tokyo, Japan).

\subsection{Staining of Tissues with the SARS-CoV-2 NP Antibody}

Tissue sections were stained with SARS-CoV-2 nucleocapsid rabbit polyclonal antibody (Thermo Fisher Scientific). The sections were treated with antigen retrieval solution in a microwave oven and blocked with normal rabbit serum in PBS ( $\mathrm{pH}$ 7.4). They were then incubated with the rabbit antibody against SARS-CoV-2 NP (1:100 dilution), and subsequently treated with biotin-labelled goat anti-rabbit immunoglobulin (Vector Laboratories, Burlingame, CA, USA), and Vectastain ABC-AP (Vector Laboratories) and Vector Red alkaline phosphatase substrate (Vector Laboratories). The labelled lung sections were counterstained with haematoxylin QS (Vector Laboratories) and observed under an Olympus DP70 microscope (Olympus Corporation).

\subsection{Measurement of Virus Titres in Terms of $\log 10$ TCID50/mL}

Vero cells grown in tissue culture flasks were detached by treatment with trypsin-EDTA and were seeded in 96-well tissue culture plates with MEM containing 10\% FBS and 1× antibiotic-antimycotic solution. When confluent, the cells were washed with warm PBS ( $\mathrm{pH} 7.4$ ) and infected with virus samples, which were 10-fold diluted in MEM with 1.5\% BSA. The cells in four wells were infected with the diluted virus samples for 4 days in a humidified incubator at $37^{\circ} \mathrm{C}$ (wild-type SARS-CoV-2 strain) or $22^{\circ} \mathrm{C}$ (cold-adapted SARS-CoV-2 vaccine strain). The cells were then fixed and permeabilised with $80 \%$ cold acetone (Samchun Pure Chemical Co., Seoul, Republic of Korea). They were subsequently incubated with SARS-CoV-2 nucleocapsid rabbit polyclonal antibody (Thermo Fisher Scientific, MA, USA) and fluorescent-labelled goat anti-rabbit antibody (Thermo Fisher Scientific, MA, USA). The titre was calculated using the method described by Muench and Reed [34].

\subsection{Assessment of the Efficacy of Vaccine in hACE-2 Transgenic Mice}

At 21 days p.v., the hACE-2 mice ( $n=8$ per group) immunised with $2 \times 10^{4}$ or $2 \times 10^{3}$ pfu of CoV-2-CNUHV03-CA22 ${ }^{\circ} \mathrm{C}$ were i.n. challenged with $50 \mu \mathrm{L}\left(2 \times 10^{4} \mathrm{pfu}\right)$ of CoV-2-KCDC03. PBS (mock)-immunised hACE-2 mice $(n=6)$ were also i.n. challenged with $50 \mu \mathrm{L}\left(2 \times 10^{4} \mathrm{pfu}\right)$ of 
CoV-2-KCDC03. PBS (mock)-vaccinated and uninfected hACE-2 mice $(n=3)$ were used as controls. The infected mice were monitored for body weight change and mortality. Six days post-challenge, three mice per virus (vaccine strain or wild-type virus)-infected group and one PBS (mock)-infected mouse were euthanized for determining virus titres in different tissues (nasal turbinate, brain, lung, and kidney) and for histopathology. Virus titres were quantified by RT-qPCR and by determining the $\log 10 \mathrm{TCID} 50 / 0.1 \mathrm{~g}$ values.

\subsection{Measurement of Neutralising Antibody Titres}

Sera ( $n=8$ per group) collected from hACE-2 mice that were i.n. immunised with $50 \mu \mathrm{L}\left(2 \times 10^{4}\right.$ or $2 \times 10^{3} \mathrm{pfu}$ ) of $\mathrm{CoV}-2-\mathrm{CNUHV} 03-\mathrm{CA} 22{ }^{\circ} \mathrm{C}$ on day 19 after vaccination were 10 -fold diluted in MEM with $1.5 \%$ BSA and then serially two-fold diluted before they were incubated with 100TCID50/mL $(100 \mu \mathrm{L}: 100 \mu \mathrm{L})$ of wild-type SARS-CoV-2 virus, CoV-2-CNUHV03 or CoV-2-KCDC03, for $1 \mathrm{~h}$ in a humidified $5 \% \mathrm{CO}_{2}$ incubator $\left(37^{\circ} \mathrm{C}\right)$. Vero cells grown in a 96-well cell culture plate were washed with warm PBS (pH 7.4) and were inoculated with a mixture of serum and virus. Cells were incubated for 4 days and checked for CPE. The titre of the neutralising antibody was determined as the reciprocal of the highest dilution of serum at which the infectivity was neutralised in $100 \%$ of the cell in wells. The assay was performed in four replicates. Sixteen sera samples collected from hACE- 2 mice before vaccination were used as controls.

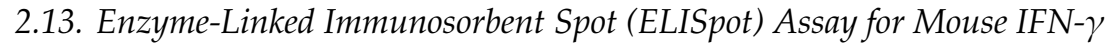

The immunised hACE-2 transgenic mice $(n=3)$ i.n. inoculated with $50 \mu \mathrm{L}\left(2 \times 10^{4} \mathrm{pfu}\right)$ of CoV-2-CNUHV03-CA2 ${ }^{\circ} \mathrm{C}$ were euthanized to collect the spleen after 19 days p.v. The spleen samples were homogenised in PBS ( $\mathrm{pH}$ 7.4) and the cells were collected. The nasal turbinates, lungs, and kidneys were homogenised in 10\% PBS ( $\mathrm{pH} 7.4$ ) and the homogenates were used for detection of IgA specific for SARS-CoV-2 by enzyme-linked immunosorbent spot (Mabtech, Nacka Strand, Sweden) assay. The collected cells were overlaid on HISTOPAQUE-1077 (Sigma-Aldrich, MO, USA) and centrifuged for $30 \mathrm{~min}$ at $1500 \mathrm{rpm}$ at $4{ }^{\circ} \mathrm{C}$. The lymphocyte layer was collected for the IFN- $\gamma$ ELISpot assay performed using the Mouse IFN- $\gamma$ ELISpotPlus kit (Mabtech, Nacka Strand, Sweden). The plate was removed from the sealed package and washed four times with sterile PBS (200 $\mu \mathrm{L} /$ well). The plate was conditioned with RPMI 1640 medium (200 $\mu \mathrm{L} /$ well) containing 10\% FBS for $30 \mathrm{~min}$ at room temperature. The purified lymphocytes (250,000/well) mixed with 0.01 m.o.i of CoV-2-CNUHV03-CA22 ${ }^{\circ} \mathrm{C}$ were added to the wells and the plate was incubated in a humidified $5 \% \mathrm{CO}_{2}$ incubator at $37^{\circ} \mathrm{C}$ for $24 \mathrm{~h}$. Thereafter, the solution was decanted from the plate and the cells were washed five times with PBS (pH 7.4) (200 $\mu \mathrm{L}$ PBS/well for each wash). The detection antibody (R4-6A2-biotin) diluted to $1 \mathrm{~g} / \mathrm{mL}$ in PBS (pH 7.4) containing 0.5\% FBS (200 $\mu \mathrm{L} /$ well) was added and the plate was incubated for $2 \mathrm{~h}$ at room temperature. The plate was washed five times with PBS ( $\mathrm{pH} 7.4)$ (200 $\mu \mathrm{L}$ PBS/well for each wash) and streptavidin-ALP (1:1000) in PBS-0.5\% FBS (100 $\mu \mathrm{L} /$ well) was added to the wells. The cells were incubated for $1 \mathrm{~h}$ at room temperature. The plate was washed five times with PBS as described above and the substrate solution (BCIP/NBT-plus) was added (100 $\mu \mathrm{L} /$ well). The plate was developed until distinct spots emerged. The colour development was stopped by extensive washing under tap water. Spots were inspected and counted under a microscope (Olympus). Three PBS (mock)-immunised hACE-2 mice were used as controls.

\subsection{Enzyme-Linked Immunosorbent Assay for Mouse TNF- $\alpha, I L-4$, and IL-10}

Splenocytes $\left(2 \times 10^{6}\right.$ per $\left.\mathrm{ml}\right)$ collected for ELISpot assay for mouse IFN- $\gamma$, were stimulated with 0.01 m.o.i of CoV-2-CNUHV03-CA22 ${ }^{\circ} \mathrm{C}$ in a humidified $5 \% \mathrm{CO}_{2}$ incubator at $37{ }^{\circ} \mathrm{C}$ for $24 \mathrm{~h}$ and the supernatants were used for detecting Th1 (TNF- $\alpha$ ) and Th2 cytokines (IL-4 and IL-10). ELISA kits for mouse TNF- $\alpha$, IL-4 and IL-10 were purchased from ThermoFisher SCIENTIIC (Waltham, MA, USA). The assay was performed according to the manufacturer's instructions. Briefly, samples and standard $(50 \mu \mathrm{l})$ were added to wells of the cytokine-coated plate and were incubated for $2 \mathrm{~h}$ at room temperature. 
The plates were washed with the wash buffer 6 times, were diluted with $100 \mu$ l of Streptavidin-HRP, and were incubated for $1 \mathrm{~h}$ at room temperature. After the plates were washed with the wash buffer 6 times, $100 \mu \mathrm{l}$ of TMB substrate was added and they were incubated for $30 \mathrm{~min}$ at room temperature. The reaction was stopped with $100 \mu \mathrm{l}$ of stop solution before the absorbance was read at $450 \mathrm{~nm}$ using a spectrophotometer (Bio-Rad, Hercules, CA, USA). The cytokine amount was calculated based on the standard curve.

\subsection{Detection of IgA Antibody Specific for SARS-CoV-2 in Tissues of Immunised Mice by Enzyme-Linked Immunosorbent Assay (ELISA)}

The purified and inactivated SARS-CoV-2 antigen (SARS-CoV-2/human/Korea/CNUHV03/2020) was diluted to a final concentration of $100 \mu \mathrm{g} / \mathrm{mL}$ in a coating buffer (carbonate-bicarbonate buffer, $\mathrm{pH}$ 9.6). The diluted antigen $(100 \mu \mathrm{L})$ was coated onto the wells of a Nunc-Immuno ${ }^{\mathrm{TM}}$ MicroWell $^{\mathrm{TM}} 96$ well solid plate (Sigma-Aldrich, MO, USA) by incubation overnight at $4{ }^{\circ} \mathrm{C}$. After removing the coating buffer, the plate was washed twice by filling the wells with $400 \mu \mathrm{L}$ of washing buffer $(0.05 \%$ Tween 20 PBS (pH 7.4) containing 4\% horse serum). To block the remaining protein-binding sites, $400 \mu \mathrm{L}$ of blocking buffer (PBS containing 4\% skimmed milk) was added to the plate and the plate was kept overnight at $4{ }^{\circ} \mathrm{C}$. The buffer was removed, and the supernatant $(100 \mu \mathrm{L})$ of the homogenised tissue (nasal turbinates, lungs, and kidneys) from vaccinated and non-vaccinated mice 19 days after vaccination, diluted 10-fold in blocking buffer, was added to the plate and incubated for $1 \mathrm{~h}$ at room temperature. The plate was washed four times with the washing buffer. Goat anti-mouse IgA cross-adsorbed secondary antibody HRP (Invitrogen, MA, USA) (100 $\mu \mathrm{L}$ ), diluted 1:5000 in blocking buffer, was added to each well and incubated for $1 \mathrm{~h}$ at room temperature. After washing the plate four times with the washing buffer, $100 \mu \mathrm{L}$ TMB ELISA substrate (MABTECH) was dispensed in each well and the plate was incubated for $30 \mathrm{~min}$ at $4{ }^{\circ} \mathrm{C}$. ABTS ${ }^{\circledR}$ Peroxidase Stop Solution (KPL, MD, USA) $(100 \mu \mathrm{L})$ was subsequently added to each well. The absorbance of the solution in each well was measured at $450 \mathrm{~nm}$ using an iMARK ${ }^{\mathrm{TM}}$ Microplate Absorbance Reader (Bio-Rad, CA, USA).

\subsection{Sequencing of the Full Genome of Cold-Adapted Live Attenuated SARS-CoV-2 Vaccine Strain}

The genome of CoV-2-CNUHV03-CA22 ${ }^{\circ} \mathrm{C}$ was fully sequenced using overlapping primers (Table S1). Viral RNA was extracted using the RNeasy Mini Kit (QIAGEN, Venlo, Netherlands). Tissue culture supernatant $(200 \mu \mathrm{L})$ containing the virus was disrupted in $350 \mu \mathrm{L}$ Buffer RLT, and then $500 \mu \mathrm{L}$ of $70 \%$ ethanol was added to the mixture. The disrupted samples $(700 \mu \mathrm{L})$ were transferred to the RNeasy Mini spin column, and the column was centrifuged for $15 \mathrm{~s}$ at 13,500 rpm. After discarding the flow-through, $700 \mu \mathrm{L}$ of RW1 buffer was added to the spin column and it was centrifuged for $15 \mathrm{~s}$ at 13,500 rpm. The flow-through was again discarded and $500 \mu \mathrm{L}$ of RPE buffer was added to the spin column, which was then centrifuged for $2 \mathrm{~min}$ at 13,500 rpm. The spin column was placed in a new $1.5 \mathrm{~mL}$ collection tube and viral RNA was eluted with $50 \mu \mathrm{L}$ of RNAse-free water. The extracted RNA was reverse transcribed to cDNAs using GoScript ${ }^{\mathrm{TM}}$ Reverse Transcription System (Promega, Madison, USA) and 12 reverse primers (covid2500R, covid5000R, covid7500R, covid10000R, covid12500R, covid15000R, covid17500R, covid20000R, covid22500R, covid25000R, covid27500R, covid29843R) (Table S2). Twelve viral genes were amplified by PCR with GoTaq Hot Start Green Master Mix (Promega) and a segment-specific primer set. Amplicons were separated by gel electrophoresis and purified using the QIAquick Gel Extraction Kit (QIAGEN). The purified genes were cloned into the pGEM-T Easy vector (Promega) and the vector construct was used for transformation of chemically competent Escherichia coli DH5 $\alpha$ cells (Enzynomics, Daejeon, Korea). The plasmids were extracted using the HiGene Plasmid Mini Prep Kit (BIOFACT, Daejeon, Korea) and the sequences were determined by Macrogen (Seoul, Korea). Three clones per segment were sequenced. The sequenced genes were arranged using DNASTAR Lasergene (Madison, WI, USA). The sequence of CoV-2-CNUHV03-CA22 ${ }^{\circ} \mathrm{C}$ was deposited in GenBank under the accession number MT810119. 


\subsection{Ethical Approval}

The protocol (202003-CNU-023) for the study of SARS-CoV-2 vaccine efficacy in mice was approved by the Internal Animal Use Committee at Chungnam National University (CNU). All the studies were approved and were conducted in accordance with the relevant legal guidelines and regulations prescribed by CNU, Republic of Korea.

\subsection{Statistical Analysis}

Differences between mice infected with cold-adapted live attenuated SARS-CoV-2 vaccine strain and wild-type SARS-CoV-2 virus or between vaccinated and PBS (mock)-infected mice were analysed by Student's t-test with IBM SPSS Statistics version 20. A value of $p<0.05$ was considered statistically significant.

\section{Results}

To develop a live attenuated vaccine for SARS-CoV-2, amenable to intranasal delivery, we gradually adapted SARS-CoV-2 isolated from a human patient (SARS-CoV-2/human/Korea/CNUHV03/2020; referred to as CoV-2-CNUHV03 in this study) (GenBank accession number: MT678839) [35] to a temperature from $37{ }^{\circ} \mathrm{C}$ to $22{ }^{\circ} \mathrm{C}$ in Vero cells cultured in an atmosphere of $5 \% \mathrm{CO}_{2}$ in a humidified incubator. When cells infected with SARS-CoV-2 showed complete cytopathic effects (CPE) at the set temperature, they were incubated at the next lower temperature. SARS-CoV-2 viruses that were successfully passaged more than five times (>passage $=5$ ) at $22^{\circ} \mathrm{C}$ were used for the vaccine efficacy study. SARS-CoV-2 adapted at $22^{\circ} \mathrm{C}$ was designated as SARS-CoV-2/human/Korea/CNUHV03-CA22 ${ }^{\circ} \mathrm{C} / 2020$ (herein referred to as $\mathrm{CoV}-2-\mathrm{CNUHV} 03-\mathrm{CA} 22^{\circ} \mathrm{C}$ ).

Vero cells grown in 6-well plates were infected with wild-type SARS-CoV-2 (CoV-2-CNUHV03) or cold-adapted vaccine SARS-CoV-2 (CoV-2-CNUHV03-CA22 $\left.{ }^{\circ} \mathrm{C}\right)$ in a humidified $5 \% \mathrm{CO}_{2}$ incubator at $37^{\circ} \mathrm{C}$ and $41^{\circ} \mathrm{C}$ to determine the temperature sensitivity of the vaccine strain (Figure S1). At $37^{\circ} \mathrm{C}$ and 0.00001 multiplicity of infections (m.o.i) (Figure S1A), the viral titres of CoV-2-CNUHV03-CA22 ${ }^{\circ} \mathrm{C}$ and CoV-2-CNUHV03 were $2.6 \times 10^{5}$ plaque forming units $(\mathrm{pfu}) / \mathrm{mL}$ and $7.9 \times 10^{5} \mathrm{pfu} / \mathrm{mL}$, respectively. At $37^{\circ} \mathrm{C}$ and 0.000001 m.o.i (Figure S1A), those of CoV-2-CNUHV03-CA22 ${ }^{\circ} \mathrm{C}$ and CoV-2-CNUHV03 were $0 \mathrm{pfu} / \mathrm{mL}$ and $7.9 \times 10^{4} \mathrm{pfu} / \mathrm{mL}$, respectively. At $41^{\circ} \mathrm{C}$ and 0.00001 m.o.i (Figure S1B), the viral titres of CoV-2-CNUHV03-CA22 ${ }^{\circ} \mathrm{C}$ and CoV-2-CNUHV03 were $0 \mathrm{pfu} / \mathrm{mL}$ and $10 \times 10^{3} \mathrm{pfu} / \mathrm{mL}$, respectively. At $41{ }^{\circ} \mathrm{C}$ and 0.000001 m.o.i. (Figure S1B), those of CoV-2-CNUHV03-CA22 ${ }^{\circ} \mathrm{C}$ and CoV-2-CNUHV03 were $0 \mathrm{pfu} / \mathrm{mL}$ and $8 \times 10^{3} \mathrm{pfu} / \mathrm{mL}$, respectively.

To confirm the attenuation of $\mathrm{CoV}-2-\mathrm{CNUHV} 03-\mathrm{CA} 22{ }^{\circ} \mathrm{C}$ in an animal, we intranasally (i.n.) infected hACE-2 transgenic mice (K18-hACE2), which are very susceptible to SARS-CoV-2, with CoV-2-CNUHV03-CA22 ${ }^{\circ} \mathrm{C}\left(2 \times 10^{4} \mathrm{pfu}\right)$ (Figure 1). The infected mice were monitored for mortality (Figure 1A) and change in body weight (Figure 1B) for 14 days. All these mice survived and did not show any loss of body weight, whereas all the K18-hACE2 mice infected with CoV-2-CNUHV03 showed loss of body weight (5.8\%) until 8 days post-infection (p.i.) and eventually died.

We measured the virus titres in different tissues (nasal turbinates, brain, lungs, kidneys, spleen) of infected mice by determining the $\log 10$ tissue culture infectious dose $50(\log 10$ TCID50) values in Vero cells as well as by performing real-time quantitative polymerase chain reaction (RT-qPCR) with SARS-CoV-2 N primers and probe on day 6 p.i. The virus titres were lower in the tissues of K18-hACE2 mice infected with CoV-2-CNUHV03-CA22 ${ }^{\circ} \mathrm{C}$ compared to the tissues of K18-hACE2 mice infected with CoV-2-CNUHV03 (Figure $1 \mathrm{C}$ and Figure S2). When we measured the virus titres in terms of the $\log 10 \mathrm{TCID} 50$ value, viruses were detected only in the lungs of K18-hACE2 mice infected with CoV-2-CNUHV03-CA22 ${ }^{\circ} \mathrm{C}$ with a titre of 1.83 TCID50/0.1g; however, the virus was detected in the nasal turbinates (3.0 TCID50/0. g), brain (7.5 TCID50/0.1 g), lungs (3.5 TCID50/0.1 g), and kidneys (3.5 TCID50/0.1 g) of K18-hACE2 mice infected with CoV-2-CNUHV03 (Figure 1C). Using RT-qPCR, the virus was detected in the nasal turbinates $\left(5.9 \times 10^{3} \mathrm{pfu} / 0.1 \mathrm{~g}\right)$ and lungs $\left(11 \times 10^{3} \mathrm{pfu} / 0.1 \mathrm{~g}\right)$ 
of K18-hACE2 mice infected with CoV-2-CNUHV03-CA22 ${ }^{\circ} \mathrm{C}$, whereas it was detected in the nasal turbinates $\left(10 \times 10^{3} \mathrm{pfu} / 0.1 \mathrm{~g}\right)$, brain $\left(2.5 \times 10^{6} \mathrm{pfu} / 0.1 \mathrm{~g}\right)$, lungs $\left(14 \times 10^{3} \mathrm{pfu} / 0.1 \mathrm{~g}\right)$, and kidneys $\left(1.3 \times 10^{3} \mathrm{pfu} / 0.1 \mathrm{~g}\right)$ of K18-hACE2 mice infected with CoV-2-CNUHV03 (Figure S2A,B). On day 14 p.i., no virus was detected in the tissues of K18-hACE2 mice infected with CoV-2-CNUHV03-CA22 ${ }^{\circ} \mathrm{C}$ (Figure 1C, Figure S2AB).
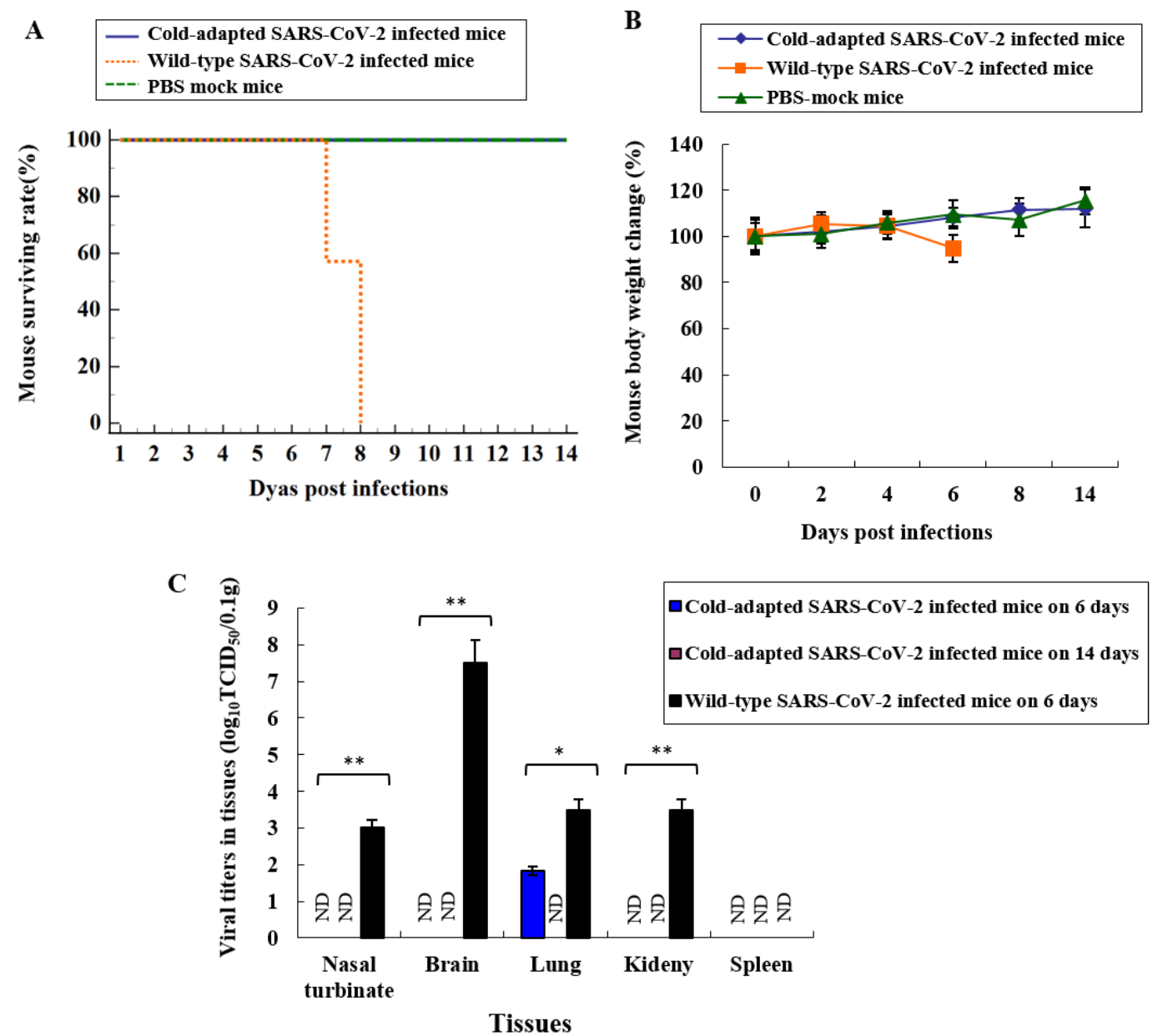

Figure 1. Attenuation of cold-adapted SARS-CoV-2 vaccine strain in hACE2 transgenic mice. K18-ACE2 mice were i.n. infected with cold adapted SARS-CoV-2 (CoV-2-CNUHV03-CA22 ${ }^{\circ} \mathrm{C}\left(2 \times 10^{4} \mathrm{pfu}\right)$ $(n=14)$ or were i.n. infected with wild-type SARS-CoV-2 (CoV-2-CNUHV03) $\left(2 \times 10^{4} \mathrm{pfu}\right)(n=10)$. Mice were monitored for mortality and the change of body weights for 14 days. On day 6 p.i., mice ( $n=3$ per group) were euthanized for viral titers in tissues. On day 14 p.i., mice $(n=3)$ infected with $\mathrm{CoV}-2-\mathrm{CNUHV} 03-\mathrm{CA} 22^{\circ} \mathrm{C}$ were also euthanized. PBS-mock infected K18-ACE-2 mice $(n=4)$ were used as a control group and among them, one mice were euthanized on day 6. (A) Mice mortality rate (\%); (B) the change of mouse body weights (\%) compared to those before infections, (C) viral titers in mouse tissues ( $n=3$ per group) of nasal turbinate, brain, lung, kidney, and spleen by $\log _{10} \mathrm{TCID}_{50} / 0.1 \mathrm{~g}$. Viral titers are the mean of 3 tissues \pm standard deviations. Detection limit of virus is $1 \mathrm{TCID}_{50} / 0.1 \mathrm{~g}$. ${ }^{*} p<0.05,{ }^{* *} p<0.001$, ND: non-detected

We stained the lung tissue sections of K18-hACE2 mice with haematoxylin and eosin (H\&E) and brain, lungs, and kidneys with the SARS-CoV-2 NP antibody (Figure 2, Figures S3 and S4). The lung tissue of K18-hACE2 mice infected with CoV-2-CNUHV03-CA22 ${ }^{\circ} \mathrm{C}$ (Figure 2B) showed much milder pneumonia than that of K18-hACE2 mice infected with CoV-2-CNUHV03 (Figure 2C) on day 6 p.i. The antigen staining in the lung of K18-hACE2 mice infected with CoV-2-CNUHV03-CA22 ${ }^{\circ} \mathrm{C}$ (Figure 2E) was much more sparse than that in mice infected with CoV-2-CNUHV03 (Figure 2F) on day 6 p.i. 
No antigen staining was observed in the brain (Figure S3B) and kidneys (Figure S3E) of K18-hACE2 mice infected with $\mathrm{CoV}-2-\mathrm{CNUHV} 03-\mathrm{CA} 22^{\circ} \mathrm{C}$ on day 6 p.i., whereas profuse antigen staining was observed in the brain (Figure S3C) and kidneys (Figure S3F) of K18-hACE2 mice infected with CoV-2-CNUHV03 on day 6 p.i. No antigen staining was observed in the lungs (Figure S4A), brain (Figure S4B), and kidney (Figure $\mathrm{S} 4 \mathrm{C}$ ) of K18-hACE2 mice infected with CoV-2-CNUHV03-CA22 ${ }^{\circ} \mathrm{C}$ on day 14 p.i.
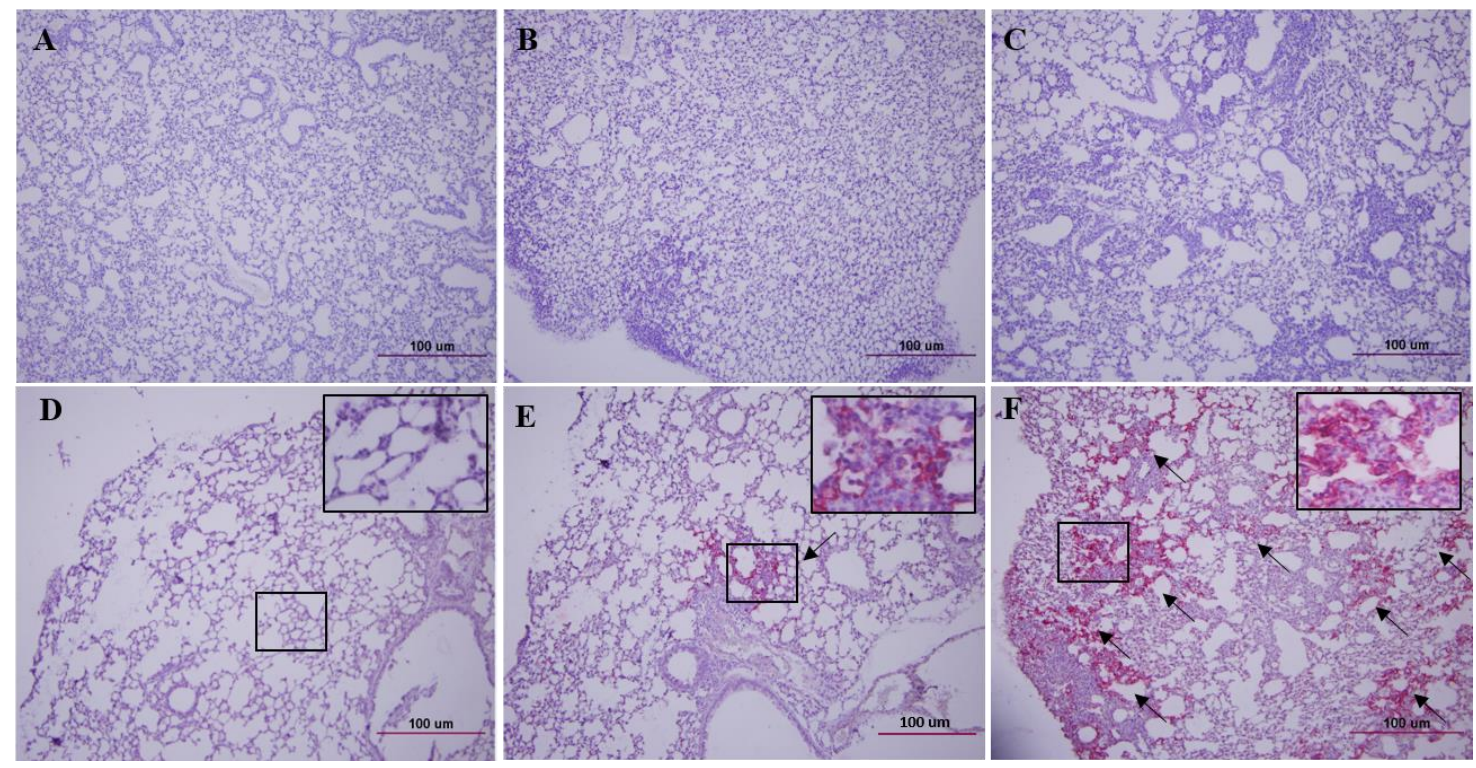

Figure 2. Lung histopathology and antigen staining of cold-adapted SARS-CoV-2 vaccine strain in hACE2 transgenic mice. Lung tissues (Figure 1C) of K18-ACE2 mice on 6 days p.i. were stained with hematoxylin and eosin $(\mathbf{A}-\mathbf{C})(\times 100)$, and SARS-CoV-2 NP antibody $(\mathbf{D}-\mathbf{F})(\times 100)$. $(\mathbf{A}, \mathbf{D})$, lung tissues of PBS-mock mice, $(\mathbf{B}, \mathbf{E})$, lung tissues of mice i.n. infected with cold adapted SARS-CoV-2 (CoV-2-CNUHV03-CA22 $\left.{ }^{\circ} \mathrm{C}\right)\left(2 \times 10^{4} \mathrm{pfu}\right),(\mathbf{C}, \mathbf{F})$, lung tissues of mice infected with wild-type SARS-CoV-2 (CoV-2-CNUHV03) $\left(2 \times 10^{4} \mathrm{pfu}\right)$. Arrow: positive antigen staining. Inlet $(\times 400)$.

K18-hACE2 mice were immunised by i.n. administration of $2 \times 10^{4}$ or $2 \times 10^{3}$ pfu of CoV-2CNUHV03-CA22 ${ }^{\circ} \mathrm{C}$, and sera were collected 19 days post vaccination (p.v.). The titre of the neutralising antibody (NA) was measured using CoV-2-CNUHV03 and CoV-2-KCDC03 in Vero cells. Strong NA titres, in the range of 640-4960, were induced in K18-hACE2 mice immunised with $2 \times 10^{4}$ (Figure 3A) or $2 \times 10^{3}$ (Figure 3B) pfu of CoV-2-CNUHV03-CA22 ${ }^{\circ} \mathrm{C}$. No NA was detected in the sera of K18-hACE2 mice, collected before vaccination (Figure S5). We measured the levels of IgA antibody, which is responsible for mucosal immunity, in the different tissues (nasal turbinates, lungs, and kidneys) using purified inactivated SARS-CoV-2 antigen (CoV-2-CNUHV03) and goat horseradish peroxidase (HRP)-labelled anti-mouse IgA antibody (Figure S6A) and T cells expressing IFN- $\gamma$ (Figure S6B). The detection of IgA indicates the induction of cellular immunity in splenocytes in K18-hACE2 mice immunised with $\mathrm{CoV}-2-\mathrm{CNUHV} 03-\mathrm{CA} 22^{\circ} \mathrm{C}\left(2 \times 10^{4} \mathrm{pfu}\right)$. IgA was detected in all the tissues that were assessed, with the highest amount detected in nasal turbinates (OD: 0.298) (Figure S6A). The number of IFN- $\gamma$ expressing T cells in the immunised and PBS (mock)-immunised K18-hACE2 mice was 1682/250,000 and 249/250,000 splenocytes, respectively (Figure S6B). In addition, when we quantified Th1 (TNF- $\alpha$ ) and Th2 cytokines (IL-4 and IL-10) in the supernatants of splenocytes from the immunized mice, in the immunized splenocytes, TNF- $\alpha(57.58 \mathrm{pg} / \mathrm{mL})$ was more strongly induced than IL-4 $(0 \mathrm{pg} / \mathrm{mL})$ and IL-10 $(0 \mathrm{pg} / \mathrm{mL})$ (Figure S7). 


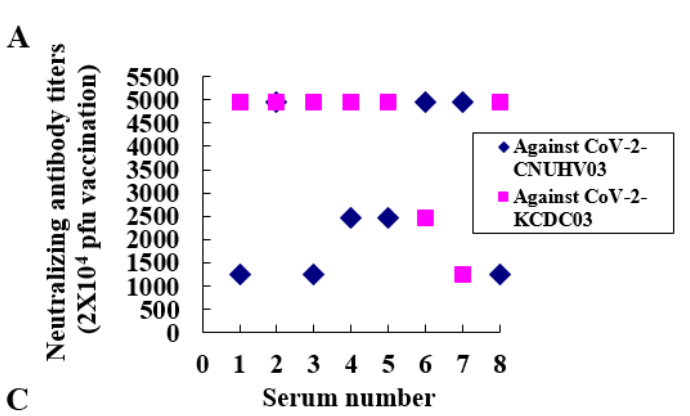

C

- Cold-adapted SARS-CoV-2 vaccinated $(20,000 \mathrm{pfu})$ \& challenged mice " " " , PBS-mock \& challenged mice W. PBS-mock \& unchallenged mice

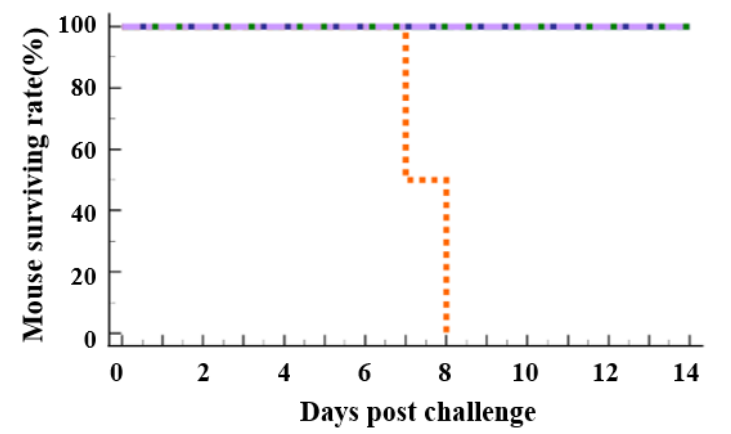

$\mathbf{E}$

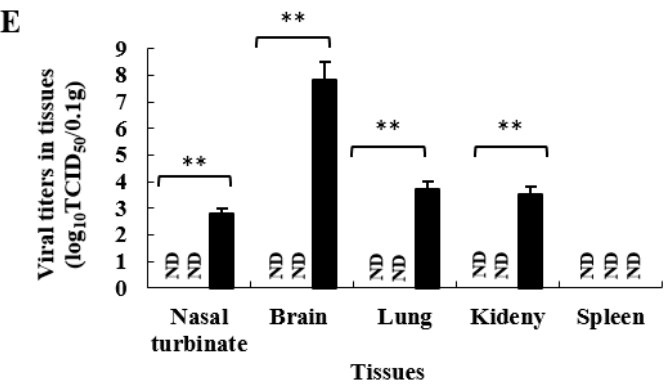

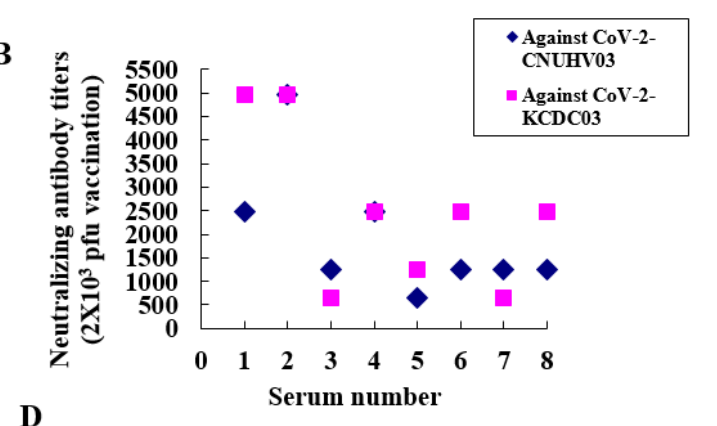
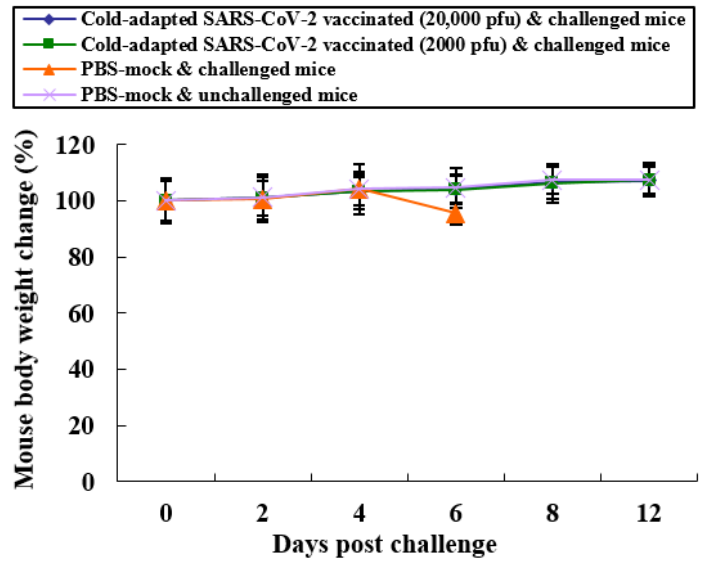

- Cold-adapted SARS-CoV-2 vaccinated (20,000 pfu) $\&$ challenged mice

-Cold-adapted SARS-CoV-2 vaccinated (2000 pfu) \& challenged mice

- PBS-mock \& challenged mice

Figure 3. Neutralizing antibodies and challenge of immunized hACE2 transgenic mice with cold-adapted SARS-CoV-2 vaccine strain. Sera collected from K18-ACE2 mice ( $n=8$ per group) immunized with $2 \times 10^{4} \mathrm{pfu}$ or $2 \times 10^{3} \mathrm{pfu}$ of cold adapted SARS-CoV-2 (CoV-2-CNUHV03-CA22 $\left.{ }^{\circ} \mathrm{C}\right)$ 19 days ago, and their neutralizing antibody titers were determined against wild-type SARS-CoV-2 viruses, CoV-2-CNUHV03 and CoV-2-KCDC03 in Vero cells. (A) Sera from immunized mice with $2 \times 10^{4}$ pfu of CoV-2-CNUHV03-CA22 ${ }^{\circ} \mathrm{C}$; (B) Sera from immunized mice with $2 \times 10^{3}$ pfu of CoV-2-CNUHV03-CA22 ${ }^{\circ} \mathrm{C}$. Sera $(n=16)$ collected before immunization were used as a control. Detection limit of neutralizing antibody is $10 .{ }^{*} p<0.05,{ }^{* *} p<0.001$. K18-ACE2 mice ( $n=8$ per group) immunized with $2 \times 10^{4}$ pfu or $2 \times 10^{3}$ pfu of cold adapted SARS-CoV-2 (CoV-2-CNUHV03-CA22 $\left.{ }^{\circ} \mathrm{C}\right)$ 21 days ago were i.n. challenged with $2 \times 10^{4}$ pfu of wild-type SARS-CoV-2 (CoV-2-KCDC03). PBS-mock vaccinated mice $(n=6)$ were also i.n. challenged with $2 \times 10^{4}$ pfu of CoV-2-KCDC03 and PBS-mock and unchallenged mice $(n=3)$ were used as a control. The challenged mice were monitored for mortality and change in body weight for 12 days. On day 6 post challenge, the challenged mice $(n=3)$ were euthanized for viral titers in tissues. One PBS-mock and unchallenged mouse was euthanized on day 6. (C) Mice mortality rate (\%); (D) the change of mouse body weights (\%) compared to those before challenge, $(\mathrm{E})$, viral titers in mouse tissues ( $n=3$ per group) of nasal turbinate, brain, lung, kidney, and spleen by $\log _{10} \mathrm{TCID}_{50} / 0.1 \mathrm{~g}$. Viral titers are the mean of 3 tissues \pm standard deviations. Detection limit of virus is $1 \mathrm{TCID}_{50} / 0.1 \mathrm{~g} .{ }^{*} p<0.05,{ }^{* *} p<0.001$, ND: non-detected.

K18-hACE2 mice were i.n. immunised with $2 \times 10^{4}$ or $2 \times 10^{3}$ pfu of CoV-2-CNUHV03-CA22 ${ }^{\circ} \mathrm{C}$ and i.n. challenged with $2 \times 10^{4}$ pfu of CoV-2-KCDC03 on 21 days p.v. The challenged K18-hACE2 
mice were monitored for mortality (Figure 3C), and change in body weight (Figure 3D) for 12 days p.i.; the virus titres in different tissues (nasal turbinates, lungs, brain, kidneys, and spleen) were measured 6 days post-challenge (p.c.) by determining the log10TCID50 values (Figure 3E) and by performing RT-qPCR (Figure S8A,B). All of the immunised and challenged K18-hACE2 mice survived (Figure 3C) and did not show loss of body weight (Figure 3D), whereas all the PBS (mock)-immunised and challenged K18-hACE2 mice died (Figure 3C) within 8 days p.c., and showed loss of body weight (4.6\%) (Figure 3D). No virus was detected in the nasal turbinates, brain, lungs, kidneys, and spleen of immunised K18-hACE2 mice determined in terms of the log10TCID50 value (Figure 3E) as well as by RT-qPCR (Figure S8A,B). Considerable virus titres were detected in the nasal turbinates $\left(2.8 \mathrm{TCID} 50 / 0.1 \mathrm{~g}, 12.0 \times 10^{3} \mathrm{pfu} / 0.1 \mathrm{~g}\right)$, brain $\left(7.8 \mathrm{TCID} 50 / 0.1 \mathrm{~g}, 2.7 \times 10^{6} \mathrm{pfu} / 0.1 \mathrm{~g}\right)$, lungs (3.7TCID50/0.1 g, $15.0 \times 10^{3} \mathrm{pfu} / 0.1 \mathrm{~g}$ ), and kidneys (3.5TCID50/0.1 g, $1.4 \times 10^{3} \mathrm{pfu} / 0.1 \mathrm{~g}$ ) in PBS (mock)-immunised and challenged K18-hACE2 mice (Figure 3E, Figure S8A,B). As in the case of PBS (mock)-immunised and unchallenged K18-hACE2 mice (Figure 4A), H\&E staining of lung tissue samples from challenged K18-hACE2 mice immunised with $2 \times 10^{3}$ pfu (Figure 4 B) and $2 \times 10^{4} \mathrm{pfu}$ (Figure $4 \mathrm{C}$ ) of $\mathrm{CoV}-2-\mathrm{CNUHV} 03-\mathrm{CA} 22{ }^{\circ} \mathrm{C}$ showed mild pneumonia and no pneumonia, respectively. The lung tissue of PBS (mock)-immunised and challenged K18-hACE2 mice exhibited severe interstitial pneumonia with infiltration of inflammatory cells (Figure 4D). As in the case of PBS (mock)-immunised and unchallenged K18-hACE2 mice (Figure 4E), no positive staining was detected with SARS-CoV-2 $\mathrm{NP}$ antibody in the lung tissues of challenged K18-hACE2 mice immunised with $2 \times 10^{3} \mathrm{pfu}$ (Figure $4 \mathrm{~F}$ ) or $2 \times 10^{4}$ (Figure $4 \mathrm{G}$ ) pfu of $\mathrm{CoV}-2-\mathrm{CNUHV} 03-\mathrm{CA} 22^{\circ} \mathrm{C}$. Numerous positively stained regions were observed in the lung tissue of PBS (mock)-immunised and challenged K18-hACE2 mice (Figure 4H). No antigen staining was observed in the brain (Figure S9B) and kidneys (Figure S9F) of challenged K18-hACE2 mice (immunised with $2 \times 10^{3} \mathrm{pfu}$ ) as well as in the brain (Figure S9C) and kidneys (Figure S9G) of challenged K18-hACE2 mice (immunised with $2 \times 10^{4} \mathrm{pfu}$ ) as was observed for the brain (Figure S9A) and kidneys (Figure S9E) of PBS (mock)-immunised and unchallenged K18-hACE2 mice. Strong positive antigen staining was found in the brain (Figure S9D) and kidneys (Figure S9H) of PBS (mock)-immunised and challenged K18-hACE2 mice.

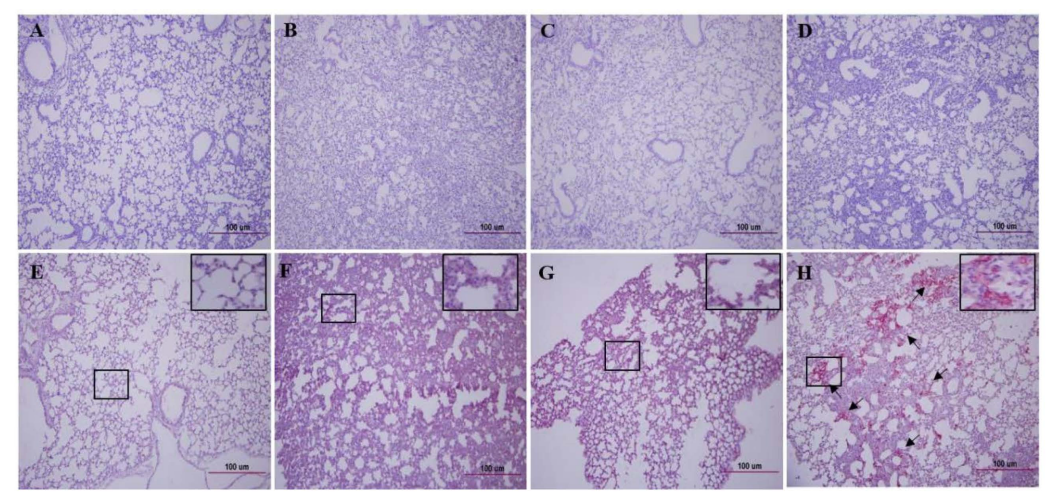

Figure 4. Lung histopathology and antigen-staining of the immunized and challenged hACE2 transgenic mice. Lung tissues (Figure 3E) of the immunized and challenged K18-ACE2 were stained with hematoxylin and eosin (A-D) $(\times 100)$ and SARS-CoV-2 NP antibody $(\mathbf{E}-\mathbf{H})(\times 100)$. (A,E), Lung tissue of PBS-mock mouse; (B,F) Lung tissue of the immunized mouse $\left(2 \times 10^{3} \mathrm{pfu}\right)$ and challenged with CoV-2-KCDC03 $\left(2 \times 10^{4} \mathrm{pfu}\right) ;(\mathbf{C}, \mathrm{G})$, Lung tissue of the immunized mouse $\left(2 \times 10^{4} \mathrm{pfu}\right)$ and challenged with CoV-2-KCDC03 $\left(2 \times 10^{4} \mathrm{pfu}\right)$; $(\mathbf{D}, \mathbf{H})$, Lung tissue of PBS-mock and challenged mouse with $\mathrm{CoV}-2-\mathrm{KCDC} 03\left(2 \times 10^{4} \mathrm{pfu}\right)$. Arrow: positive antigen staining. Inlet $(\times 400)$.

We fully sequenced the genes of $\mathrm{CoV}-2-\mathrm{CNUHV} 03-\mathrm{CA} 22^{\circ} \mathrm{C}$ and compared the sequences with those of wild-type SARS-CoV-2 (CoV-2-CNUHV03) (Table 1, Tables S3 and S4, Figures S10 and S11). Among the 29,874 nucleotides, 59 including 37 nonsynonymous substitutions and 22 synonymous substitutions occurred in $\mathrm{CoV}-2-\mathrm{CNUHV} 03-\mathrm{CA} 22^{\circ} \mathrm{C}$ compared to those of $\mathrm{CoV}-2-\mathrm{CNUHV03}$ (Table S3 and Figure S10). Among the 9755 amino acid residues, 31 were mutated in $\mathrm{CoV}-2-\mathrm{CNUHV} 03-\mathrm{CA} 22^{\circ} \mathrm{C}$ 
compared to that in CoV-2-CNUHV03 (Table S4, Figure S11). To identify the possible unique mutations in CoV-2-CNUHV03-CA22 ${ }^{\circ} \mathrm{C}$, we compared the changed amino acids in CoV-2-CNUHV03-CA22 ${ }^{\circ} \mathrm{C}$ with those in the genes of SARS-CoV-2 present in GenBank (https://www.ncbi.nlm.nih.gov/nuccore) and GISAID (https://www.gisaid.org/), and found 11 such amino acids out of 9755 amino acids in CoV-2-CNUHV03-CA22 ${ }^{\circ} \mathrm{C}$ (Table 1). In nsp2 (non-structural protein 2), with no known function [36], amino acid residues from 82 to 84 (glycine $(\mathrm{G})$, histidine $(\mathrm{H})$, and valine $(\mathrm{V})$ ) were deleted, and there was one mutation (M (methionine) $85 \mathrm{~V}$ ). In nsp6, which functions as a potential transmembrane scaffold protein [37], two mutations (N (asparagine) 3609K (lysine), D (aspartic acid) 3671T (threonine)) were present, and in $\mathrm{nsp7}$, which functions as a processivity clamp for RNA polymerase [38], one mutation (D3926A (alanine)) was present. In helicase (nsp13) acting as RNA 5'-triphosphatase [39], one mutation (L (leucine)5604F (phenylalanine)) was present, and in S protein, which binds to the receptors [40], three mutations (T95I (isoleucine), N185K, S (Serine)968A) were present. Sequence analyses of the genome of the cold-adapted live attenuated SARS-CoV-2 vaccine strain (CoV-2-CNUHV03-CA22 ${ }^{\circ} \mathrm{C}$ ) in lung tissues of infected K18-ACE2 mice on day 6 p.i. revealed no reverted changes in genes (data not shown). The viral growth titre of cold-adapted live attenuated SARS-CoV-2 vaccine strain in Vero cells in tissue culture flask $\left(75 \mathrm{~cm}^{2}\right)$ at $22{ }^{\circ} \mathrm{C}$ is about $2.7 \times 10^{6} \mathrm{pfu} / \mathrm{mL}$, which is very comparable to that $\left(3.0 \times 10^{6} \mathrm{pfu} / \mathrm{mL}\right)$ of wild type SARS-CoV-2 (CoV-2-CNUHV03) at $37^{\circ} \mathrm{C}$ (data not shown).

Table 1. Unique sequences of amino acids in cold-adapted live attenuated SARS-CoV-2 vaccine strain (SARS-CoV-2/human/Korea/CNUHV03-CA22 $\left.{ }^{\circ} \mathrm{C} / 2020\right)$.

\begin{tabular}{|c|c|c|c|c|}
\hline & Protein Name & & $\begin{array}{l}\text { Difference of Amino } \\
\text { Acid Sequences }\end{array}$ & $\begin{array}{l}\text { The Number of } \\
\text { Changed Sequence }\end{array}$ \\
\hline \multirow{4}{*}{ ORF1ab polyprotein } & \multirow{3}{*}{ ORF1a polyprotein } & nsp2 & Deletion: GHV(82 84), M85V & $4 / 641$ \\
\hline & & nsp6 & N3609K, D3671T & $2 / 290$ \\
\hline & & nsp7 & D3926A & $1 / 83$ \\
\hline & ORF1b & helicase & L5604F & $1 / 601$ \\
\hline & S protein & & T95I, N185K, S968A & $3 / 1274$ \\
\hline \multicolumn{4}{|c|}{ Total amino acids } & $\begin{array}{l}\text { 11/9755 (including } \\
\text { nonchanged ORFs) }\end{array}$ \\
\hline
\end{tabular}

We compared the amino acid sequences of SARS-CoV-2/human/Korea/CNUHV03-CA22 ${ }^{\circ} \mathrm{C} / 2020$ with those in GenBank (https://www.ncbi.nlm.nih.gov/nuccore) and GISAID (https://www.gisaid.org/). We found out the unique amino acids in our cold-adapted live attenuated SARS-CoV-2 vaccine strain (SARS-CoV-2/human/Korea/CNUHV03-CA22 ${ }^{\circ} \mathrm{C} / 2020$ ). Single letter abbreviation name of amino acid: Glycine(G), Alanine(A), Valine(V), Leucine(L), Isoleucine(I), Methionine(M), Phenylalanine(F), Serine(S), Threonine(T), Asparagine(N), Lysine(K), Histidine(H), Aspartic Acid(D).

\section{Discussion}

SARS-CoV-2 has been continuously spreading in humans since December 2019. Several efforts have been made by scientists around the world to develop safe and effective vaccines to prevent SARS-CoV-2 infection in humans [41]. Since March 2020, we have been in the process of developing a cold-adapted live attenuated SARS-CoV-2 vaccine that can elicit mucosal and cellular immunity and can be administered through the nasal route in humans. Our strategy had been to gradually adapt SARS-CoV-2 virus to temperatures from $37^{\circ} \mathrm{C}$ to $22^{\circ} \mathrm{C}$ in Vero cells. We confirmed the efficacy of the developed cold-adapted live attenuated SARS-CoV-2 vaccine (CoV-2-CNUHV03-CA22 $\left.{ }^{\circ} \mathrm{C}\right)$ in K18-hACE2 mice, which can be readily infected with SARS-CoV-2 and succumb to death upon infection.

We developed a cold-adapted live attenuated vaccine for SARS-CoV-2 by adapting it to grow in Vero cells at $22^{\circ} \mathrm{C}$. This vaccine strain was found to be sensitive to temperatures of $37^{\circ} \mathrm{C}$ and $4{ }^{\circ} \mathrm{C}$. The currently used live attenuated vaccine (nasal spray vaccine) for seasonal influenza viruses (influenza A and B viruses) was developed by adapting the virus to multiply in primary chicken kidney cells and embryonated eggs at temperatures up to $25{ }^{\circ} \mathrm{C}$. Nasal spray influenza vaccines for the 2019-2020 season contained four influenza viruses (influenza A (H1N1) virus, influenza A (H3N2) virus, and two influenza B viruses). Nasal spray influenza vaccines are approved for use in non-pregnant individuals who are 2 years to 49 years of age [42]. 
A strong neutralising antibody (640 to 4960) was induced in all the 16 immunised K18-hACE2 mice, which were i.n. inoculated with one dose $\left(2 \times 10^{4}\right.$ or $\left.2 \times 10^{3} \mathrm{pfu}\right)$ of CoV-2-CNUHV03-CA22 ${ }^{\circ} \mathrm{C}$. SARS-CoV-2-specific IgA antibody was also induced in the nasal turbinates, lungs, and kidneys. In addition, $\mathrm{T}$ lymphocytes expressing IFN- $\gamma$, which are specific for SARS-CoV-2, were strongly induced in the spleen of vaccinated mice at 19 days p.i. In a study on a measles virus (MeV)-based vaccine expressing the spike protein of SARS-CoV-2 (MeVvac2-SARS-S (H)) [16], it was observed that after the second immunisation, the neutralising antibody titre for measles virus in all the immunised mice ranged from 257 to 800, but the titre against SARS-CoV-2 ranged from 15 to 80 in three out of six immunised mice. Some sera from the immunized mice with cold-adapted SARS-CoV-2 showed higher NA titres to heterologous SARS-CoV-2-KCDC03 than to vaccine parental SARS-CoV-2-CNUHV03. It seems that three mutated amino acids in $S$ protein in the vaccine strain and the immune status of individual mice influenced NA antibody titres. It is necessary to use more diverse SARS-CoV-2 strains for the NA assay to determine the antigenicity difference.

We showed that all of the K18-hACE2 mice i.n. immunised with one dose $\left(2 \times 10^{4}\right.$ or $\left.2 \times 10^{3} \mathrm{pfu}\right)$ of CoV-2-CNUHV03-CA22 ${ }^{\circ} \mathrm{C}$ were completely protected from the infection of wild-type SARS-CoV-2 (CoV-2-KCDC03) and did not show any loss of body weight, or detection of virus in different tissues (nasal turbinates, brain, lungs, kidneys) in terms of the log10TCID50 values or as determined by RT-qPCR. The study on the adenovirus-based ChAdOX1 nCoV-19 vaccine, expressing the spike protein of SARS-CoV-2, showed significantly reduced virus titres in bronchoalveolar lavage fluid and respiratory tract tissues of vaccinated rhesus macaques that were challenged with SARS-CoV-2 [43].

We used Vero E6 cells to develop the cold-adapted live attenuated SARS-CoV-2 vaccine strain, which is immunogenic to hACE2-tg mice. The recent study showed that the propagation of SARS-CoV-2 in Vero E6 cells could lead to mutations of amino acids at the S1/S2 cleavage site of S protein [44]. To overcome these mutations, it may be useful to use Vero cells expressing TMPRSS2, in which SARS-CoV-2 may be propagated as well [45]. The antigenicity of SARS-CoV-2 vaccine strain grown in Vero cells needs to be monitored before it is used as a human vaccine.

In the present study, we used two doses of cold-adapted live attenuated SARS-CoV-2 vaccine to assess its protective efficacy due to the limited availability of human hACE2-tg mice provided by the Jackson Laboratory (USA). We recently started to breed more hACE2-tg mice in our animal facility. As hACE2-tg mice become more available, various doses of cold-adapted live attenuated SARS-CoV-2 vaccine will be used to investigate the minimal effective dose in hACE2-tg mice.

No animal model can represent the clinical signs of humans infected with SARS-CoV-2. Infected humans show clinical outcomes that range from mild to severe, including deaths [7]. SARS-CoV-2 infections were lethal in hACE-2-tg mice from the Jackson laboratory, which can be used to model severe cases of humans; whereas, other SARS-CoV-2-infected animals, such as Syrian golden hamsters [46], ferrets [47], and non-human primates [48], show mild clinical signs such as pneumonia and fever without deaths, and can represent the mild cases of humans.

\section{Conclusions}

In conclusion, cold-adapted live attenuated SARS-CoV-2 vaccine (CoV-2-CNUHV03-CA22 $\left.{ }^{\circ} \mathrm{C}\right)$ is safe in K18-hACE2 mice, and one-dose vaccination can completely protect K18-hACE2 mice from the challenge of SARS-CoV-2.

Supplementary Materials: The following are available online at http://www.mdpi.com/2076-393X/8/4/584/s1, Figure S1. Temperature sensitivity of cold-adapted SARS-CoV-2 vaccine strain. Vero cells were infected with 0.00001 or 0.000001 m.o.i of cold-adapted SARS-CoV-2 vaccine strain $\left(\mathrm{CoV}-2-\mathrm{CNUHV} 03-\mathrm{CA} 22^{\circ} \mathrm{C}\right)$ or wild-type SARS-CoV-2 (CoV-2-CNUHV03) and were incubated at $37^{\circ} \mathrm{C}$ or $41^{\circ} \mathrm{C}$ for 3 days. Viral titers in cell supernatants were determined by RT-qPCR using SARS-CoV-2 N primers and probe. Viral detection limit is 10 pfu. A, viral titers at $37^{\circ} \mathrm{C}$; B, viral titers at $41^{\circ} \mathrm{C}$. ${ }^{*} p<0.05,{ }^{* *} p<0.001$, ND: non-detected. Figure S2. Viral titers in tissues of hACE2 transgenic mice infected with cold adapted SARS-CoV-2. Viral titers in tissues of Figure 1C were quantified RT-qPCR. Viral titers are the mean of 3 tissues \pm standard deviations. Viral detection limit is 10 pfu. A, viral titers in nasal turbinate, lung, kidney, and spleen, B, viral titers in brain. ${ }^{*} p<0.05,{ }^{* *} p<0.001, \mathrm{ND}$ : non-detected. Figure S3. Antigen staining in brain and kidney of hACE2 transgenic mice infected with cold adapted 
SARS-CoV-2. Brain and kidney tissues of Figure 1C (on day 6 p.i.) were stained with SARS-CoV-2 NP antibody $(\times 100)$. A, brain tissue of PBS-mock mouse; B, brain tissue of mouse i.n. infected with cold adapted SARS-CoV-2 (CoV-2-CNUHV03-CA22 $\left.{ }^{\circ} \mathrm{C}\right)\left(2 \times 10^{4} \mathrm{pfu}\right)$; C, brain tissue of mouse i.n. infected with wild-type SARS-CoV-2 (CoV-2-CNUHV03) $\left(2 \times 10^{4} \mathrm{pfu}\right)$; D, kidney tissue of PBS-mock mouse; E, kidney tissue of mouse i.n. infected with cold adapted SARS-CoV-2 (CoV-2-CNUHV03-CA22 $\left.{ }^{\circ} \mathrm{C}\right)\left(\left(2 \times 10^{4} \mathrm{pfu}\right) ; \mathrm{F}\right.$, kidney tissue of mouse i.n. infected with wild-type SARS-CoV-2 (CoV-2-CNUHV03) $\left(2 \times 10^{4} \mathrm{pfu}\right)$. Arrow: positive antigen staining. Inlet $(\times 400)$, Figure S4. Antigen staining in lung, brain and kidney of hACE2 transgenic mice infected with cold adapted SARS-CoV-2 on day 14 p.i. Lung, brain and kidney tissues of Figure 1 (on day 14 p.i.) were stained with SARS-CoV-2 NP antibody $(\times 100)$. A, lung tissue of mouse i.n. infected with cold adapted SARS-CoV-2 (CoV-2-CNUHV03-CA22 $\left.{ }^{\circ} \mathrm{C}\right)\left(2 \times 10^{4} \mathrm{pfu}\right) ; \mathrm{B}$, brain tissue of mouse i.n. infected with cold adapted SARS-CoV-2 (CoV-2-CNUHV03-CA22 $\left.{ }^{\circ} \mathrm{C}\right)\left(2 \times 10^{4} \mathrm{pfu}\right)$; C, kidney tissue of mouse i.n. infected with cold adapted SARS-CoV-2 (CoV-2-CNUHV03-CA22 $\left.{ }^{\circ} \mathrm{C}\right)\left(2 \times 10^{4} \mathrm{pfu}\right)$. Inlet $(\times 400)$, Figure S5. Neutralizing antibody titers in sera collected from hACE2 transgenic mice before immunization. Sera were collected from K18-ACE2 mice $(n=16)$ before immunization, and their neutralizing antibody titers were determined against wild-type SARS-CoV-2 viruses, CoV-2-CNUHV03 and CoV-2-KCDC03 in Vero cells. Detection limit of neutralizing antibody is 10. ND: non-detected, Figure S6. IgA antibody titers and the number of T lymphocytes expressing IFN-g in the immunized hACE2 transgenic mice. The immunized K18-ACE2 mice $(n=3)$ with $2 \times 10^{4}$ pfu of CoV-2-CNUHV03-CA22 ${ }^{\circ} \mathrm{C}$ were euthanized to collect tissues (nasal turbinate, lungs, kidneys, spleens) on 19 days after immunization. Nasal turbinate, lungs, and kidneys were homogenized in PBS and were used for detection of IgA antibody by ELISA using the purified and inactivated SARS-CoV-2 antigen (SARS-CoV-2/human/Korea/CNUHV03/2020). Lymphocytes were collected from spleens and used to determine the number of T lymphocytes expressing IFN-g by ELISPOT assay. Data are the mean of 3 tissues \pm standard deviations. A, IgA antibody titers; B, number of T lymphocytes expressing IFN-g. ${ }^{*} p<0.05,{ }^{* *} p<0.001$, Figure S7. Detection of Th1 and Th2 cytokines in splenocytes from the immunized hACE2 transgenic mice. Splenocytes of Figure S6B were stimulated with cold-adapted SARS-CoV-2 vaccine for $24 \mathrm{~h}$, and their supernatants were used for detecting TNF-a, IL-4 and IL-10. Data are the mean of 3 tissues \pm standard deviations. ${ }^{* *} p<0.001$; ND: non-detected, Figure S8. Viral titers in tissues of the immunized and challenged hACE2 transgenic mice. Viral titers in tissues of Figure 3E were quantified RT-qPCR. Viral titers are the mean of 3 tissues \pm standard deviations. Viral detection limit is $10 \mathrm{pfu}$. A, viral titers in nasal turbinate, lung, kidney, and spleen; B, Viral titer in brain. ${ }^{*} p<0.05,{ }^{* *} p<0.001$, ND: non-detected, Figure S9. Antigen staining in brain and kidney of the immunized and challenged hACE2 transgenic mice. Brain and kidney tissues of challenged K18-ACE2 mice (Figure 3E) were stained with SARS-CoV-2 NP antibody $(\times 400)$. A, brain tissue of PBS-mock mouse; B, brain tissue of vaccinated mouse with CoV-2-CNUHV03-CA22oC $\left(2 \times 10^{3}\right.$ pfu $)$ and challenged with CoV-2-KCDC03 $\left(2 \times 10^{4} \mathrm{pfu}\right)$; C, brain tissue of vaccinated mouse with CoV-2-CNUHV03-CA22oC $\left(2 \times 10^{4} \mathrm{pfu}\right)$ and challenged with CoV-2-KCDC03 $\left(2 \times 10^{4} \mathrm{pfu}\right) ; \mathrm{D}$, brain tissue of PBS-mock vaccinated mouse challenged with CoV-2-KCDC03 $\left(2 \times 10^{4} \mathrm{pfu}\right)$; E, kidney tissue of PBS-mock mouse; F, kidney tissue of vaccinated mouse with CoV-2-CNUHV03-CA2 ${ }^{\circ} \mathrm{C}\left(2 \times 10^{3} \mathrm{pfu}\right)$ and challenged with CoV-2-KCDC03 $\left(2 \times 10^{4} \mathrm{pfu}\right)$; $\mathrm{G}$, kidney tissue of vaccinated mouse with CoV-2-CNUHV03-CA22 ${ }^{\circ} \mathrm{C}\left(2 \times 10^{4} \mathrm{pfu}\right)$ and challenged with CoV-2-KCDC03 $\left(2 \times 10^{4} \mathrm{pfu}\right) ; \mathrm{H}$, kidney tissue of PBS-mock vaccinated mouse challenged with CoV-2-KCDC03 $\left(2 \times 10^{4} \mathrm{pfu}\right)$. Arrow: positive antigen staining, Figure S10. Nucleotide alignment of cold-adapted live attenuated SARS-CoV-2 vaccine strain. Full nucleotide sequences of cold-adapted live attenuated SARS-CoV-2 vaccine strain (CoV-2-CNUHV 03-CA22 $\left.{ }^{\circ} \mathrm{C}\right)$ were aligned with that of wild-type SARS-CoV-2 (CoV-2-CNUHV03) using DNASTAR Lasergene, Figure S11. Amino acid alignment of cold-adapted live attenuated SARS-CoV-2 vaccine strain. Full amino acid sequences of cold-adapted live attenuated SARS-CoV-2 vaccine strain (CoV-2-CNUHV03-CA22 $\left.{ }^{\circ} \mathrm{C}\right)$ were aligned with that of wild-type SARS-CoV -2 (CoV-2-CNUHV03) using DNASTAR Lasergene. Table S1. Primers used for PCR amplification of the gene segments in cold-adapted live attenuated SARS-CoV-2 vaccine strain (SARS-CoV-2/human/Korea/CNUHV03-CA22 $\left.{ }^{\circ} \mathrm{C} / 2020\right)$, Table S2. Primers for the synthesis of cDNA for cold-adapted live attenuated SARS-CoV-2 vaccine strain (SARS-CoV-2/human/Korea/CNUHV03-CA22 ${ }^{\circ} \mathrm{C}$ /2020), Table S3. The changed nucleotide sequences in cold-adapted live attenuated SARS-CoV-2 vaccine strain (SARS-CoV-2/human/Korea/CNUHV03-CA22 ${ }^{\circ} \mathrm{C} / 2020$ ), Table S4. Changed amino acid sequences in cold-adapted live attenuated SARS-CoV-2 vaccine strain (SARS-CoV-2/human/Korea/CNUHV03-CA22 ${ }^{\circ} \mathrm{C} / 2020$ ).

Author Contributions: S.H.S. designed the study: developed cold-adapted live attenuated SARS-CoV-2 vaccine strain, performed the cold sensitivity of vaccine strain, all animal study and antigen staining of tissues, analyzed the data, and wrote the manuscript. Y.J. sequenced the genome of cold-adapted live attenuated SARS-CoV-2 vaccine and performed the staining of tissues with H\&E. All authors have read and agreed to the published version of the manuscript.

Funding: This research received no external funding.

Conflicts of Interest: All authors declare that they have no competing interests.

\section{References}

1. Zhu, N.; Zhang, D.; Wang, W.; Li, X.; Yang, B.; Song, J.; Zhao, X.; Huang, B.; Shi, W.; Lu, R.; et al. A novel coronavirus from patients with pneumonia in China. N. Engl. J. Med. 2019, 382, 727-733. [CrossRef] 
2. Li, Q.; Guan, X.; Wu, P.; Wang, X.; Zhou, L.; Tong, Y.; Ren, R.; Leung, K.S.M.; Lau, E.H.Y.; Wong, J.Y.; et al. Early transmission dynamics in Wuhan, China, of novel coronavirus-infected pneumonia. N. Engl. J. Med. 2020, 382, 1199-1207. [CrossRef]

3. Coronaviridae Study Group of the International Committee on Taxonomy of Viruses. The species Severe acute respiratory syndrome-related coronavirus: Classifying 2019-nCoV and naming it SARS-CoV-2, Version 2. Nat. Microbiol. 2020, 5, 536-544. [CrossRef] [PubMed]

4. Wu, A.; Peng, Y.; Huang, B.; Ding, X.; Wang, X.; Niu, P.; Meng, J.; Zhu, Z.; Zhang, Z.; Wang, J.; et al. Genome composition and divergence of the novel Coronavirus (2019-nCoV) originating in China. Cell Host Microbe 2020, 27, 325-328. [CrossRef] [PubMed]

5. Liu, Z.; Xiao, X.; Wei, X.; Li, J.; Yang, J.; Tan, H.; Zhu, J.; Zhang, Q.; Wu, J.; Liu, L. Composition and divergence of coronavirus spike proteins and host ACE2 receptors predict potential intermediate hosts of SARS-CoV-2. J. Med. Virol. 2020, 92, 595-601. [CrossRef] [PubMed]

6. Zhai, X.; Sun, J.; Yan, Z.; Zhang, J.; Zhao, J.; Zhao, Z.; Gao, Q.; He, W.T.; Veit, M.; Su, S. Comparison of severe acute respiratory syndrome coronavirus 2 spike protein binding to ace2 receptors from human, pets, farm animals, and putative intermediate hosts. J. Virol. 2020, 94, e00831-20. [CrossRef]

7. Wang, D.; Hu, B.; Hu, C.; Zhu, F.; Liu, X.; Zhang, J.; Wang, B.; Xiang, H.; Cheng, Z.; Xiong, Y.; et al. Clinical characteristics of 138 hospitalized patients with 2019 novel coronavirus-infected pneumonia in Wuhan, China. JAMA 2020, 323, 1061-1069. [CrossRef]

8. Chen, N.; Zhou, M.; Dong, X.; Qu, J.; Gong, F.; Han, Y.; Qiu, Y.; Wang, J.; Liu, Y.; Wei, Y.; et al. Epidemiological and clinical characteristics of 99 cases of 2019 novel coronavirus pneumonia in Wuhan, China: A descriptive study. Lancet 2020, 395, 507-513. [CrossRef]

9. Arentz, M.; Yim, E.; Klaff, L.; Lokhandwala, S.; Riedo, F.X.; Chong, M.; Lee, M. Characteristics and outcomes of 21 critically Ill patients with COVID-19 in Washington State. JAMA 2020, 323, 1612-1614. [CrossRef]

10. Słyk, S.; Domitrz, I. Neurological manifestations of SARS-CoV-2-A systemic review. Neurol. Neurochir. Polska 2020. [CrossRef]

11. Gupta, I.; Reddy, M.K.; Hussain, M.M.; Murthy, P.M.; Robert, C.A. Atypical neurological manifestations of COVID-19. Cureus 2020, 12, e8518. [CrossRef] [PubMed]

12. Smith, T.R.F.; Patel, A.; Ramos, S.; Elwood, D.; Zhu, X.; Yan, J.; Gary, E.N.; Walker, S.N.; Schultheis, K.; Purwar, M.; et al. Immunogenicity of a DNA vaccine candidate for COVID-19. Nat. Commun. 2020, 11, 2601. [CrossRef] [PubMed]

13. Mulligan, M.J.; Lyke, K.E.; Kitchin, N.; Absalon, J.; Gurtman, A.; Lockhart, S.P.; Neuzil, K.; Raabe, V.; Bailey, R.; Swanson, K.A.; et al. Phase 1/2 study to describe the safety and immunogenicity of a COVID-19 RNA vaccine candidate (BNT162b1) in adults 18 to 55 years of age: Interim report. MedRxiv 2020. [CrossRef]

14. Jackson, L.A.; Anderson, E.J.; Rouphael, N.G.; Roberts, P.C.; Makhene, M.; Coler, R.N.; McCullough, M.P.; Chappell, J.D.; Denison, M.R.; Stevens, L.J.; et al. An mRNA vaccine against SARS-CoV-2-Preliminary report. N. Engl. J. Med. 2020, 2022483. [CrossRef] [PubMed]

15. Folegatti, P.M.; Ewer, K.J.; Aley, P.K.; Angus, B.; Becker, S.; B-Rammerstorfer, S.; Bellamy, D.; Bibi, S.; Bittaye, M.; Clutterbuck, E.A.; et al. Safety and immunogenicity of the ChAdOx1 nCoV-19 vaccine against SARS-CoV-2: A preliminary report of a phase 1/2, single-blind, randomised controlled trial. Lancet 2020, 396, 467-478. [CrossRef]

16. Hörner, C.; Schürmann, C.; Auste, A.; Ebenig, A.; Muraleedharan, S.; Herrmann, M.; Schnierle, B.; Mühlebach, M.D. A highly immunogenic measles virus-based Th1-biased COVID-19 Vaccine. bioRxiv 2020. [CrossRef]

17. Case, J.B.; Rothlauf, P.W.; Chen, R.E.; Kafai, N.M.; Fox, J.M.; Shrihari, S.; McCune, B.T.; Harvey, I.B.; Smith, B.; Keeler, S.P. Replication-competent vesicular stomatitis virus vaccine vector protects against SARS-CoV-2-mediated pathogenesis. Cell Host Microbe 2020, 28, 30421-30422. [CrossRef] [PubMed]

18. Yqhqlom-Ronen, Y.; Tamir, H.; Melamed, S.; Politi, B.; Shifman, O.; Achdout, H.; Vitner, E.B.; Israeli, O.; Milrot, E.; Stein, D.; et al. A single dose of recombinant VSV- $\Delta \mathrm{G}$-spike vaccine provides protection against SARS-CoV-2 challenge. bioRxiv 2020. [CrossRef]

19. Gao, Q.; Bao, L.; Mao, H.; Wang, L.; Xu, K.; Yang, M.; Li, Y.; Zhu, L.; Wang, N.; Lv, Z. Development of an inactivated vaccine candidate for SARS-CoV-2. Science 2020, 369, 77-81. [CrossRef]

20. Demicheli, V.; Rivetti, A.; Debalini, M.G.; Di Pietrantonj, C. Vaccines for measles, mumps and rubella in children. Cochrane Database Syst. Rev. 2012, 2012, CD004407. [CrossRef] 
21. Hilleman, M.R.; Buynak, E.B.; Weibel, R.E.; Stokes, J. Live, attenuated mumps-virus vaccine. N. Engl. J. Med. 1968, 278, 227-232. [CrossRef] [PubMed]

22. Parkman, P.D.; Meyer, H.M.; Kirschstein, R.L.; Hopps, H.E. Development and characterization of a live attenuated rubella virus. J. Pediatrics 2018, 69, 893. [CrossRef]

23. O’Ryan, M. Rotarix (RIX4414): An oral human rotavirus vaccine. Expert Rev. Vaccines 2007, 6, 11-19. [CrossRef] [PubMed]

24. Seward, J.F.; Watson, B.M.; Peterson, C.L.; Mascola, L.; Pelosi, J.W.; Zhang, J.X.; Maupin, T.J.; Goldman, G.S.; Tabony, L.J.; Brodovicz, K.G.; et al. Varicella disease after introduction of varicella vaccine in the United States, 1995-2000. JAMA 2002, 287, 606-611. [CrossRef] [PubMed]

25. Barrett, A.D.T. Yellow fever vaccines. Biologicals 1997, 25, 17-25. [CrossRef]

26. Maassab, H.F. Adaptation and growth characteristics of influenza virus at 25 degrees c. Nature 1967, 213, 612-614. [CrossRef] [PubMed]

27. Block, S.L.; Yogev, R.; Hayden, F.G.; Ambrose, C.S.; Zeng, W.; Walker, R.E. Shedding and immunogenicity of live attenuated influenza vaccine virus in subjects 5-49 years of age. Vaccine 2008, 26, 4940-4946. [CrossRef] [PubMed]

28. Oladunni, F.S.; Park, J.; Tamayo, P.P.; Gonzalez, O.; Akhter, A.; A-Guardia, A.; Olmo-Fontánez, A.; Gautam, S.; Garcia-Vilanova, A.; Ye, C.; et al. Lethality of SARS-CoV-2 infection in K18 human angiotensin converting enzyme 2 transgenic mice. bioRxiv 2020. [CrossRef]

29. Moreau, G.B.; Burgess, S.L.; Sturek, J.M.; Donlan, A.N.; Petri, W.A., Jr.; Mann, B.J. Evaluation of K18-hACE2 mice as a model of SARS-CoV-2 infection. Am. J. Trop. Med. Hyg. 2020, 103. [CrossRef]

30. Rathnasinghe, R.; Strohmeier, S.; Amanat, F.; Gillespie, V.L.; Krammer, F.; García-Sastre, A.; Coughlan, L.; Schotsaert, M.; Uccellini, M. Comparison of transgenic and adenovirus hACE2 mouse models for SARS-CoV-2 infection. bioRxiv 2020. [CrossRef]

31. Winkler, E.S.; Bailey, A.L.; Kafai, N.M.; Nair, S.; McCune, B.T.; Yu, J.; Fox, J.M.; Chen, R.E.; Earnest, J.T.; Keeler, S.P. SARS-CoV-2 infection in the lungs of human ACE2 transgenic mice causes severe inflammation, immune cell infiltration, and compromised respiratory function. bioRxiv 2020. [CrossRef]

32. McCray, P.B., Jr.; Pewe, L.; Wohlford-Lenane, C.; Hickey, M.; Manzel, L.; Shi, L.; Netland, J.; Jia, H.P.; Halabi, C.; Sigmund, C.D. Lethal infection of K18-hACE2 mice infected with severe acute respiratory syndrome coronavirus. J. Virol. 2007, 81, 813-821. [CrossRef] [PubMed]

33. Corman, V.M.; Landt, O.; Kaiser, M.; Molenkamp, R.; Meijer, A.; Chu, D.K.; Bleicker, T.; Brünink, S.; Schneider, J.; Schmidt, M.L.; et al. Detection of 2019 novel coronavirus (2019-nCoV) by real-time RT-PCR. Euro Surveill. 2020, 25, 2000045. [CrossRef] [PubMed]

34. Reed, L.J.; Muench, H. A simple method of estimating fifty percent endpoints. Am. J. Hyg. 1938, $27,493-497$.

35. Jang, Y.; Seo, S.H. Gene expression pattern differences in primary human pulmonary epithelial cells infected with MERS-CoV or SARS-CoV-2. Arch. Virol. 2020, 165, 2205-2211. [CrossRef] [PubMed]

36. Graham, R.L.; Sims, A.C.; Brockway, S.M.; Baric, R.S.; Denison, M.R. The nsp2 replicase proteins of murine hepatitis virus and severe acute respiratory syndrome coronavirus are dispensable for viral replication. J. Virol. 2005, 79, 13399-19411. [CrossRef]

37. Oostra, M.; Hagemeijer, M.C.; Gent, M.V.; Bekker, C.P.J.E.; te Lintelo, G.; Rottier, P.J.M.; de Haan, C.A.M. Topology and membrane anchoring of the coronavirus replication complex: Not all hydrophobic domains of nsp3 and nsp6 are membrane spanning. J. Virol. 2008, 82, 12392-12405. [CrossRef]

38. Zhai, Y.; Sun, F.; Li, X.; Pang, H.; Xu, X.; Bartlam, M.; Rao, Z. Insights into SARS-CoV transcription and replication from the structure of the nsp7-nsp8 hexadecamer. Nat. Struct. Mol. Biol. 2005, 12, 980-986. [CrossRef]

39. Ivanov, K.A.; Ziebuhr, J. Human coronavirus 229E nonstructural protein 13: Characterization of duplex-unwinding, nucleoside triphosphatase, and RNA 5'-triphosphatase activities. J. Virol. 2004, 78, 7833-7838. [CrossRef]

40. Wan, Y.; Shang, J.; Graham, R.; Baric, R.S.; Li, F. Receptor recognition by the novel coronavirus from Wuhan: An analysis based on decade-long structural studies of SARS coronavirus. J. Virol. 2020, 94, e00127-20. [CrossRef]

41. Word Health Organization. Draft Landscape of COVID-19 Candidate Vaccines. Available online: https: //www.who.int/publications/m/item/draft-landscape-of-covid-19-candidate-vaccines (accessed on 20 July 2020). 
42. Centers for Disease Control and Prevention. Attenuated Influenza Vaccine [LAIV] (The Nasal Spray Flu Vaccine). Available online: https://www.cdc.gov/flu/prevent/nasalspray.htm (accessed on 9 July 2020).

43. Doremalen, N.V.; Lambe, T.; Spencer, A.; Belij-Rammerstorfer, S.; Purushotham, J.N.; Port, J.R.; Avanzato, V.; Bushmaker, T.; Flaxman, A.; Ulaszewska, M.; et al. ChAdOx1 nCoV-19 vaccination prevents SARS-CoV-2 pneumonia in rhesus macaque. Nature 2020. [CrossRef]

44. Ogando, N.S.; Dalebout, T.J.; Zevenhoven-Dobbe, J.C.; Limpens, R.W.; Van Der Meer, Y.; Caly, L.; Druce, J.; De Vries, J.J.C.; Kikkert, M.; Bárcena, M.; et al. SARS-coronavirus-2 replication in Vero E6 cells: Replication kinetics, rapid adaptation and cytopathology. J. Gen. Virol. 2020, jgv001453. [CrossRef] [PubMed]

45. Matsuyama, S.; Nao, N.; Shirato, K.; Kawase, M.; Saito, S.; Takayama, I.; Nagata, N.; Sekizuka, T.; Katoh, H.; Kato, F.; et al. Enhanced isolation of SARS-CoV-2 by TMPRSS2-expressing cells. Proc. Natl. Acad. Sci. USA 2020, 117, 7001-7003. [CrossRef] [PubMed]

46. Imai, M.; Iwatsuki-Horimoto, K.; Hatta, M.; Loeber, S.; Halfmann, P.J.; Nakajima, N.; Watanabe, T.; Ujie, M.; Takahashi, K.; Ito, M.; et al. Syrian hamsters as a small animal model for SARS-CoV-2 infection and countermeasure development. Proc. Natl. Acad. Sci. USA 2020, 117, 16587-16595. [CrossRef] [PubMed]

47. Shi, J.; Wen, Z.; Zhong, G.; Yang, H.; Wang, C.; Huang, B.; Liu, R.; He, X.; Shuai, L.; Sun, Z.; et al. Susceptibility of ferrets, cats, dogs, and other domesticated animals to SARS-coronavirus 2. Science 2020, 368, 1016-1020. [CrossRef]

48. Hartman, A.L.; Nambulli, S.; McMillen, C.M.; White, A.G.; Tilston-Lunel, N.L.; Albe, J.R.; Cottle, E.; Dunn, M.D.; Frye, L.J.; Gilliland, T.H.; et al. SARS-CoV-2 infection of African green monkeys results in mild respiratory disease discernible by PET/CT imaging and shedding of infectious virus from both respiratory and gastrointestinal tracts. PLoS Pathog. 2020, 16, e1008903. [CrossRef]

(C) 2020 by the authors. Licensee MDPI, Basel, Switzerland. This article is an open access article distributed under the terms and conditions of the Creative Commons Attribution (CC BY) license (http://creativecommons.org/licenses/by/4.0/). 